\title{
INSIGHTS INTO LENDER LIABILITY: AN ARGUMENT FOR TREATING GONTROLLING GREDITORS AS CONTROLLING SHAREHOLDERS
}

\author{
JEFFREY JOHN HASS $\dagger$
}

When a corporation receives a $\$ 10,000$ loan from a bank, it has got itself a full-fledged banker. But when that same corporation receives a $\$ 10,000,000$ loan from a bank, not only does it have a full-fledged banker, but also something akin to a partner.

\section{-Professor Robert G. Turner*}

The statement above was intended as common sense advice to aspiring corporate financial officers. Today, however, bankers, other creditors, and the attorneys for these two groups could benefit greatly by keeping this advice in mind. Indeed, debtors, debtor shareholders, and competing creditors recently have been challenging the work-out practices of financial institutions and other creditors more than ever before. ${ }^{1}$ Their battle cry is one of unfairness or maltreatment; their allegation is one of excessive control. However, no primary legal theory of liability is found among the cases in this area ${ }^{2}$-only the theme of influence or control recurs. ${ }^{3}$ Consequently, when a financial institution

$\dagger$ B.S. 1984, Florida State University; J.D. Candidate 1988, University of Pennsylvania; formerly with Sun Bank, N.A., Orlando, Florida.

* Old financial witticism as related by Professor Robert G. Turner, Professor of Banking at Florida State University, Lecture (Spring Term, 1984).

1 See Whitney v. Citibank, N.A., 782 F.2d 1106 (2d Cir. 1986) (holding bank liable for damages resulting from its participation in misconduct of copartners); K.M.C. Co. v. Irving Trust Co., 757 F.2d 752 (6th Cir. 1985) (holding creditor liable for damages to debtor resulting from creditor's refusal to advance funds to debtor pursuant to financing agreement); State Nat'l Bank v. Farah Mfg. Co., 678 S.W.2d 661 (Tex. Ct. App. 1984) (holding creditor liable in tort for damage to debtor's business resulting from creditor's interference). See generally Latest Boom: Suing Your Banker, U.S. News and World RePort, July 28, 1986, at 33 (discussing the trend towards suing financial institutions based on a theory of lender liability for excessive control); Moss, Borrowers Fight Back with Lender Liability, A.B.A. J., March 1, 1987, at 65 (providing a summary of several current theories of lender liability); Victor, Lender-Liability Doctrine Gives Creditors Clout, NaT'L L.J. Sept. 1, 1986, at 1 (also discussing suits against financial institutions).

${ }^{2}$ See infra text accompanying notes 32-100.

s See Douglas-Hamilton, Creditor Liabilities Resulting from Improper Interference with the Management of a Financially Troubled Debtor, 31 Bus. LAw. 343, 343 (1975). Douglas-Hamilton breaks down the cases concerning creditor liability into 
begins functioning more like a partner and less like a creditor, the courts may provide a financially distressed debtor and its entourage with a legal alternative to economic collapse.

The purpose of this Comment is to provide further insight into the creditor control issue by looking at it in light of principles of corporate law, especially the doctrine of controlling shareholder liability. Two purposes are served by comparing and contrasting the authority that a creditor may exercise over its debtor with the influence that a controlling shareholder may exert over her corporation. First, additional justification for imposing liability on creditors in certain situations is made available to the courts. Second, creditors are provided with normative guidelines with which to follow in order to limit the likelihood of successful challenges to their control.

Part I of this Comment discusses the conflicts inherent in the creditor-debtor relationship that give rise to the need for creditor control. Part II then separates the major common law theories of creditor control liability ${ }^{4}$ into three categories: improper acquisition of control by a creditor; subsequent abuse by a creditor of its legitimately acquired control; and excessive involvement of a creditor with its debtor. Part III begins by developing the similarities between controlling creditors, ordinary shareholders, and controlling shareholders. It then argues that if the characteristics of a controlling creditor mirror those of a controlling shareholder in particular instances, then the fiduciary obligations that the controlling shareholder must fulfill should likewise be satisfied by the controlling creditor. Finally, it considers exactly what a controlling creditor's fiduciary duties might entail if these duties were imposed upon it.

\section{The NeEd for Greditor Control}

The exact degree of control a creditor may exert over its debtor to legally protect its investment has been the subject of debate over the

three broad categories: (1) cases involving equitable adjustment of creditors' claims in bankruptcy or reorganization proceedings, (2) cases involving liability under federal securities laws and other regulatory statutes, and (3) cases involving liability under common law theories of recovery. She adds: "Although the equitable, statutory and common law goals differ in the cases, all share one important characteristic: the examination by the court of a creditor's dealings with its debtor to determine whether the creditor by such dealings assumed control of the debtor." Id.

1 Those interested in creditor liability in general should also consult the following articles: Douglas-Hamilton, supra note 3; Kunkel, The Fox Takes Over the Chicken House: Creditor Interference with Farm Management, 60 N.D.L. REv. 445 (1984); Lundgren, Liability of a Creditor in a Control Relationship with Its Debtor, 67 MARQ. L. Rev. 523 (1984). 
years. A consensus exists, however, that some degree of creditor control is needed. "Undeniably a lender has a clear right to impose proper conditions [on the debtor] in order to enhance its security and increase the probability that it will be repaid: that is the essence of the lending business."

Generally, lenders employ various control devices in order to guard against two situations that could arise after a loan is closed. First, the debtor's financial strength could decline prior to the loan's maturity. Such a decline is always possible even though the debtor's operations were sufficiently stable at the inception of the loan period and the debtor thereafter operated its business in good faith. ${ }^{6}$ Changes in external factors, such as a shift in consumer preferences away from the borrower's product, might negatively influence its business if not anticipated. Proper control devices, therefore, provide a lender with the ability to protect its interests in the event that the borrower confronts economic adversity. ${ }^{?}$

Second, the debtor may misbehave for a variety of reasons, especially as a response to changing market conditions. Acts of debtor misbehavior can include asset substitution, ${ }^{8}$ conversion, ${ }^{8}$ unauthorized ex-

S Koch, Bankruptcy Planning for the Secured Lender, 99 Banking L.J. 788, 799 (1982); see also Committee on Developments in Business Financing, Structuring and Documenting Business Financing Transactions Under the Federal Bankruptcy Code of 1978, 35 Bus. LAw. 1645, 1663 (1980) ("Clearly, a lender may, through covenants or similar means, affect the conduct of a debtor in order to protect the indebtedness owing to it and to monitor matters of legitimate concern with respect thereto without automatically being considered in 'control' of the debtor."); see generally Scott, A Relational Theory of Secured Financing, 86 Colum. L. REv. 901, 931 (1986) ("[E]xpected gains from the relational creditor's participation in developing growth opportunities [within the debtor] will accrue to all participants in the venture, including equity claimants and unsecured creditors."); Williamson, Corporate Governance, 93 YALE L.J. 1197, 1211 (1984) (arguing that in certain atypical circumstances lenders may even deserve representation on the debtor corporation's board of directors).

- See McCarter, Unsecured Bank Loans, in BanK CRedir 127, 136-37 (H. Prochnow ed. 1981).

7 Id.; see also R. Brealy \& S. Myers, Principles of Corporate Finance 502 (2d ed. 1984) ("Lenders don't want to wait until the [debtor] company is worthless - they want an opportunity to demand repayment at the first sign of trouble. That is why they impose a number of hurdles for the company to jump.").

${ }^{8}$ This useful laundry list of acts of debtor misbehavior comes from Scott, supra note 5. "Asset substitution" occurs when a debtor, after a credit contract has been negotiated and signed, uses a creditor's money for a more risky business project than the investment contemplated by the creditor when the agreement for financing was negotiated. See Scott, supra note 5, at 919; Smith and Warner, On Financial Contracting: An Analysis of Bond Covenants, 7 J. FIN. ECoN. 117, 118-19 (1979).

9 "Conversion" in this context occurs when the debtor converts business assets to private use, e.g., as when a debtor syphons assets from the cooperative venture to activities that are wholly owned by it. See Scott, supra note 5, at 919-20. 
pansion of liabilities, ${ }^{10}$ pursuit of ill-advised ventures, ${ }^{11}$ and failure to fully develop profitable opportunities. ${ }^{12}$ These infractions, which have been described as breaches of a debtor's "moral duty,"13 greatly reduce a creditor's chances of recouping its principal and interest. The potential for misbehavior, which normally cannot be fully anticipated at the time the debtor and the creditor enter into their agreement, ${ }^{14}$ provides a creditor with a powerful incentive to incorporate various control devices into its loan agreement in an attempt to prevent or at least contain such misbehavior. ${ }^{15}$

Loan documentation frequently contains two related control devices of particular importance in the creditor liability context: debtor's representations and warranties and loan covenants. "Representations and warranties state the assumptions upon the basis of which the loan is to be made . . ."16 In other words, they set out the particular condition of a debtor's affairs that exists at the time the agreement is executed. Typical representations and warranties found within a standard loan agreement include a debtor's attestations that it has no indebtedness, that its assets are not encumbered, and that it is not subject to any

10 "Expansion of additional risky debt" involves the debtor diluting the creditor's claim through the issuance of additional risky debt that "will compete with the claim of the initial ... [creditor] in any distribution of assets upon default." Scott, supra note 5 , at 920 .

11 For purposes of this Comment, "pursuance of ill-advised ventures" would include those projects that the lender believes to be financially unworthy, yet out of its desire to maintain a profitable, ongoing lending relationship with the debtor finances them on a fully secured basis.

12 "Underinvestment" or "inadequate effort" encompasses the disincentive for the debtor to vigorously pursue a viable project once it has sold off a portion of the payoffs resulting from the new project to others. Scott argues that the debtor's efforts instead will be diverted to those activities and investments in which the debtor retains all of the returns. See Scott, supra note 5, at 920-21.

13 See Clark, The Duties of the Corporate Debtor to Its Creditors, 90 HaRv. L. REv. 505, 510-11 (1977). Clark argues that a debtor has a moral duty before transferring his property to shareholders, self, family, friends, and shrewder or more powerful bargaining parties to give primacy to the legitimate claims of standard contract and tort creditors.

14 See Goetz \& Scott, Principles of Relational Contracts, 67 VA. L. REv. 1089, 1092 (1981) (stating that the existence of unknown contingencies in relational contracts, like the ones between debtors and creditors, prevents the "specification of precise performance standards"). See generally McCarter, supra note 6, at 137 (arguing that lenders should always allow for a margin of error since "[v]ery frequently anticipations are not always fully realized").

16 See Zimmerman, An Approach to Writing Loan Agreement Covenants, in Glassics in Commercial Bank Lending 213, 214, 217 (W. Sihler ed. 1981). See generally McCarter, supra note 6 , at 127, 136 (discussing the influence gained over the debtor's behavior through the use of a loan agreement). (1981).

${ }^{16}$ Nassberg, Loan Documentation: Basic but Crucial, 36 Bus. LAw. 843, 850 
pending or threatened litigation. ${ }^{17}$ Representations and warranties are important because most, if not all, lenders rely at least partially on the existence of the attested state of their potential debtors' affairs when making lending decisions. This importance is underscored by the fact that false representations or warranties made by the borrower could constitute a default, thus allowing the lender to accelerate the maturity of the borrower's obligation. ${ }^{18}$

Loan covenants, on the other hand, "serve to maintain the assumptions [found in the representations and warranties] by requiring certain acts of the borrower, and prohibiting others." 19 Covenants protect the lender in relation to competing creditors if the borrower's fi-

17 See Cunningham, Term Loans, in Bank CREdit 236, 243 (H. Prochnow ed. 1981) (providing a list of principal items covered within a borrower's representations and warranties).

18 See id. at 246. Cunningham states:

Upon breach of certain provisions in the agreement, the borrower may be granted a period of time after notice by the lender to remedy the breach, and if this is not done, an event of default occurs. In some situations an event of default may be automatic, requiring no action by the lender to accelerate maturity, while in other instances it may be required that the lender notify the borrower that the lender has declared the obligation due and payable. Following are common default provisions:

1. Any representation or warranty by the borrower in connection with the agreement proves to be materially false

2. Nonpayment of principal when due

3. Nonpayment of interest within a specified time after it becomes due (usually up to ten days)

4. Breach of any negative covenants

5. Default upon or failure to pay any other obligation when due

6. Bankruptcy of the borrower

7. Failure of the borrower to deny and have vacated within a specified time any bankruptcy or reorganization proceedings instituted against it (frequently 30 days)

8. Appointment of a trustee or receiver for a substantial part of the borrower's property in any involuntary proceeding and not vacated within a specific time (frequently 30 days)

9. Consent by the borrower to appointment of a trustee or receiver for a substantial part of its property

10. Assignment by the borrower for the benefit of creditors or admission by him in writing of inability to pay debts as they become due

11. Failure of the borrower to discharge any judgment against it within a specified time (frequently 30 days)

12. Breach of any other provision (including an affirmative covenant) of the agreement which is not remedied within a specified period after written notice from the lender (frequently 15 to 30 days).

Id.

19 Nassberg, supra note 16, at 850; see also Zimmerman, supra note 15, at 213, 214, 219 (discussing the function of loan covenants). 
nancial position declines. ${ }^{20}$ Furthermore, clearly delineated debtor obligations, such as those found in loan covenants, coupled with corresponding sanctions for noncompliance, aid in the prevention, detection, and punishment of debtor misbehavior. ${ }^{21}$ The credit strength of the borrower and the likelihood that that particular borrower will misbehave determine the degree to which covenants are used and the manner in which they are drafted. ${ }^{22}$ Covenant breaches, like the making of false representations or warranties, could constitute an event of default and provide the lender with the opportunity to declare the debtor's obligation immediately due and payable. $^{23}$

Although the types of covenants vary greatly, covenants themselves are generally classified as being either affirmative or negative. Affirmative covenants, which help to ensure that the debtor actively nurtures its creditworthiness, set out particular actions or events that the debtor must cause to occur or exist in the future. ${ }^{24}$ Typical affirmative covenants include requirements that the debtor properly maintain its inventory and equipment, timely secure the requisite liability and casualty insurance consistent with industry standards, and promptly pay all taxes, assessments, and similar fees. ${ }^{25}$

Of particular interest in the creditor liability context are affirmative covenants that require the debtor to submit information concerning its operations to the creditor. The scope of these submissions is characteristically broad:

Illustrative of ... [affirmative] covenants are [those] ... requiring the submission of quarterly and annual, or other periodic, audited and unaudited financial statements

${ }^{20}$ See Cunningham, supra note 17, at 244; see also McDaniel, Are Negative Pledge Clauses in Public Debt Issues Obsolete?, 38 Bus. LAw. 867, 873 (1983) ("Covenants are an institutional lender's substitute for a liquid investment. Since [a lender] ... must stay with the issuer in good times and bad, covenants enable the lender to monitor its investment and police the issuer's activities.").

${ }^{21}$ See Goetz \& Scott, The Mitigation Principle: Toward a General Theory of Contractual Obligations, 69 VA. L. REv. 967, 977-78 (1983) (stating that an unambiguous, categorical statement of performance responsibilities reduces the risk of evasion of contractual obligations).

${ }_{22}$ See Cunningham, supra note 17, at 245.

${ }^{23}$ See supra note 18 (discussing common default provisions).

24 See Zimmerman, supra note 15, at 216; see also R. Brealey \& S. MYers, supra note 7, at 503 (discussing "positive" or "affirmative" covenants with regard to bond indentures).

${ }_{25}$ Other affirmative covenants include those requiring the continuance of the debtor's corporate existence, the debtor's purchase of life insurance on "key" corporate officials, the debtor's continued use of the same accounting standards currently employed, the debtor's maintenance of various financial ratios and, importantly, the debtor's placement of its checking accounts at the lending institution. See Zimmerman, supra note 15 , at $221-25$. 
and supplementary reports ... ; the submission to the lender of copies of all reports made to shareholders, the Securities and Exchange Commission, and the Internal Revenue Service; the reporting of all material possibly pending or threatened litigation or other proceedings; notification of any proposed changes of location; and the undertaking to immediately notify the lender, at any time, of the occurrence of any event of default or event which ... could become an event of default. ${ }^{26}$

The lender's ability to gain information about the debtor's operations exceeds the ability of the typical shareholder to obtain information about her company:

Stockholders have the general right to obtain information from management about the firm's operations. This right, however, is limited and applies only to information which if released would not injure the competitive position of the firm. Often stockholders have to make a diligent effort, including taking the firm to court, in order to secure information. ${ }^{27}$

Shareholders have limited access to information due to fundamental considerations:

Obviously, a corporation cannot have its business affairs disturbed by allowing every stockholder to go through any record the stockholder would like to inspect. A corporation could not wisely permit a competitor who happened to buy shares of its common stock to look at all the corporation records. There must be, and there are, practical limitations to . . . [a shareholder's] right [to information]. ${ }^{28}$

${ }^{28}$ Nassberg, supra note 16, at 851; see also Zimmerman, supra note 15, at 214 (discussing a lender's attempt to ensure regular and frequent communication with the borrower through the use of covenants).

27 G. Pinches, Essentials of Financial Management 513 (1984).

28 J. Weston \& E. Brigham, Managerial Finance 484 n.1 (6th ed. 1978). Case law holds that most corporate records are not public records open to the perusal of all. See Stowe v. Harvey, 241 U.S. 199, 200-01 (1916); A \& K R.R. Materials, Inc. v. Green Bay and W. R.R., 437 F. Supp. 636, 644 (E.D. Wis. 1977). The major exception is the shareholders' right of access to the corporation's list of shareholders. But this right does not apply to other corporate books and records. See In re LTV Securities Litigation, 89 F.R.D. 595, 609-10 (N.D. Tex. 1981). In order to access other corporate records besides the shareholder list, the shareholder seeking access must allege a proper purpose for seeing them. See Skoglund v. Ormand Indus., 372 A.2d 204, 207 (Del. Ch. 1976). For example, a shareholder's purpose was held to be improper where he sought access to shareholder records to facilitate a merger involving the corporation and, as a 
Creditors' broad access to information, coupled with zealous use of that access, ${ }^{29}$ provides them with the ability to act quickly to protect their investments in debtors.

A final significant control device is the negative covenant. Negative covenants prohibit the debtor from engaging in enumerated acts that the creditor considers deleterious to the debtor's continued creditworthiness. Typical covenants found within a loan agreement forbid the acquisition or sale of significant capital assets, the changing of the borrower's business direction, the distribution of dividends other than from net earnings, the repurchase of stock, and the payment of excessive officer salaries. ${ }^{30}$ The use and enforcement of negative covenants, however, may give rise to allegations that the financial institution has excessively controlled the debtor to the detriment of both shareholders and competing creditors. Particularly risky covenants include those "requiring the borrower to at all times maintain management acceptable to the lender... and those... which would serve to give the lender voting control of the borrower."31

In summary, a creditor needs to exercise control over its debtor in order to protect itself from the decline in its debtor's financial strength and the possibility that its debtor might misbehave. The major devices enabling a creditor to influence the way in which its debtor operates

stockbroker, to secure a profit on this merger. See White v. Jacobsen Mfg. Co., 293 F. Supp. 1358 (E.D. Wis. 1968).

However, even though a shareholder's purpose is otherwise proper, the right to inspect books and records still is balanced against the corporation's interest in nondisclosure. See State ex. rel. Armour \& Co. v. Gulf Sulphur Corp., 231 A.2d 470, 473 (Del. 1967). In addition, many jurisdictions require the interested shareholder to comply with formal procedures, such as putting her request for information in writing, before her request need be considered by the corporation. See Kuzmickey v. Dunmore Corp., 420 F. Supp. 226, 231 (E.D. Pa. 1976). See generally E. FolK, The DelaWARE General CoRporation Law § 220 (1972) (discussing Delaware statutory provisions and case law concerning a shareholder's right of inspection).

${ }^{29}$ John McCarter sums up a lender's avid pursuit of pertinent information as follows: "An essential trait for sound [financial] analysis is an innate curiosity [on the part of the lending officer]. The lender must constantly ask himself, why? when? where? how? An inquiring attitude is essential for an adequate understanding of the situation." McCarter, supra note 6, at 135. Charles Zimmerman adds: "To make competent, ongoing lending decisions, the account officer must have an intimate understanding of the borrower. Full disclosure . . . aids the lender in maintaining . . . close control over the loan relationship." Zimmerman, supra note 15, at 219 (emphasis added). A superb discussion of the manner in which lenders are able to gather information concerning debtors from both inside and outside sources is found in H. Redding, Sources of Credit Information for Bank Credit Departments, in BANK CREDIT 48 (H. Prochnow ed. 1981).

so See Cunningham, supra note 17, at 244-45; Zimmerman, supra note 15 , at 225-28; see also R. BREALY \& S. MYERS, supra note 7, at 502 (discussing negative covenants with regard to bond indentures).

31 Nassberg, supra note 16 , at 852. 
include debtor's representations and warranties and loan covenants. Lender control, however, has been challenged. Part II below sets forth three categories of challenges to control and focuses on the legal theories that fall into each of these categories.

\section{Gategories of Greditor Control Liability}

Courts have become more amenable to suits brought against lenders and other creditors by debtors and their entourage. ${ }^{32}$ In fact, recent decisions have forced bank lawyers into a panic because of the multimillion-dollar verdicts won by disgruntled borrowers against several of the country's largest financial institutions. ${ }^{33}$ Perhaps the most curious aspect of this trend is not the actual awards themselves, but the courts' willingness to listen to and accept a myriad of theories upon which control liability could be based. As a result, banks and their lawyers have little guidance as to which circumstances and theories actually do provide a basis for control liability.

32 See Douglas-Hamilton, Troubled Debtors: The Fine Line Between Counseling and Controlling, in Classics in Commercial BaNk Lending 398, 399 (1981) (stating that although the theories for creditor control liability have been around for some time, suits seeking to impose liability are part of a "fast-growing new trend").

ss See Whitney v. Citibank, N.A., 782 F.2d 1106 (2d Gir. 1986) (court affirmed trial court verdict for general and punitive damages in the amount of $\$ 236,677.25$ and $\$ 1,500,000$, respectively); K.M.C. Co. v. Irving Trust Co., 757 F.2d 752 (6th Cir. 1985 ) (court affirmed a $\$ 7,500,000$ jury verdict against Irving Trust for its unlawful termination of K.M.C.'s revolving credit facility); Jewell v. Bank of America, No. 112439 (Sonoma County Cal. Sup. Ct. 1986) (jury award of $\$ 46.6$ million, reduced by trial judge to $\$ 22$ million; appeal pending); State Nat'l Bank v. Farah Mfg. Co., 678 S.W.2d 661 (Tex. Ct. App. 1984) (appellate court reduced the jury award of damages by $\$ 300,105$ and affirmed the judgment as reduced in the amount of $\$ 18,647,243.77$ with interest at a rate of 9 percent per annum from the date of judgment until paid); Victor, supra note 1 , at 1 .

Although the purpose of this Comment is not to ponder why this is occurring, one possibility might be a more intensified awareness of the plight of financially troubled debtors, which, in turn, has resulted in greater and more frequent jury awards to plaintiffs in these types of cases. See Cappello, Banking Malpractice?, CASE \& COMMENT, Sept.-Oct. 1986, at 3, 6. Indeed, the plight of the debtor is colorfully captured in the following scenario drawn by $\mathrm{H}$. Ronald Kibel:

Everything seems to fall apart when your company finds itself in trouble. Trusted advisers-attorneys, accountants, and consultants-run for cover, pointing their trembling index fingers at those key executives who failed to heed their sage advice. Past supporters-banks and financial institutions ... - are suddenly less cordial. The kind, understanding bank executive with whom you occasionally lunched (and who may have even paid the bill) is replaced by an older, hardened, usually bald-headed man ... [who] threatens to call in your loan, reduce your level of credit, ... take over your home ... [, and $]$... ask for your children as hostages.

H. Kibel, How to Turn Around a Financially Troubled Company 1 (1982). 
This section breaks up challenges to creditor control into three categories. The first contains challenges based on the improper acquisition of control by a creditor over a debtor. The second focuses on challenges based on a creditor's subsequent abuse of legitimately acquired control. The third and final category addresses challenges alleging that a creditor's involvement with its debtor has become "excessive."

Within each of these categories only common law theories of control liability are discussed. Other challenges that incorporate the theme of control, such as actions based on equitable subordination ${ }^{34}$ or violations of various securities laws, ${ }^{36}$ however, do exist and practitioners

s4 The theme of control also arises in the bankruptcy and securities laws contexts. Bankruptcy courts, for instance, have the ability to subordinate claims of creditors under the doctrine of equitable subordination. See 11 U.S.C. $§ 510(c)$ (1982). This section of the Bankruptcy Code provides:

$\S 510$. Subordination

(c) Notwithstanding subsections (a) and (b) of this section, after notice and a hearing, the court may-

(1) under principles of equitable subordination, subordinate for purposes of distribution all or part of an allowed claim to all or part of another allowed claim or all or part of an allowed interest to all or part of another allowed interest; or

(2) order that any lien securing such a subordinated claim be transferred to the estate.

Id.

An excellent example of the control issue arising in the equitable subordination context is found in Bergquist v. First Nat'l Bank (In re American Lumber Co.), 5 Bankr. 470 (Bankr. D. Minn. 1980). The bank in this case forced the debtor to convey an eleventh-hour security interest in its remaining unencumbered assets, at a time when the bank knew of the debtor's financial troubles, and then foreclosed on all its security interests. The bank orchestrated a gradual liquidation of the debtor for its sole benefit. Further inequitable conduct occurred during the process of liquidation, because the bank: (1) cut corporate officers' salaries significantly; (2) caused the discharge of all the debtor's employees not needed to assist with the liquidation; (3) allowed the debtor to pay other creditors only when such payment was in its best interest, as determined by the bank; (4) monitored the debtor's mail; and (5) acted as the sole signatory on a corporate bank account. $I d$. at 474 . The court, in response, ordered the complete subordination of the bank's secured claims to the claims of the general creditors, since the bank had used its control in such an abusive manner. "Good faith," " the court stated, is key, and "[a] transaction is not done in good faith if the earmarks of an arm's-length transaction are missing." Id. at 477 (citation omitted).

For more information on equitable subordination and the way in which control plays a factor, see Chaitman, The Equitable Subordination of Bank Claims, 39 Bus. LAw. 1561 (1984); DeNatale and Abram, The Doctrine of Equitable Subordination as Applied to Nonmanagement Creditors, 40 Bus. LAw. 417 (1985).

${ }^{35}$ A lender may run afoul of the securities laws in a variety of situations. With regard to control in the sense that it is addressed within this Comment, secondary liability can be imposed on the lender for violations of either section 15 of the Securities Act of 1933 or section 20 of the Securities and Exchange Act of 1934:

\section{Section 15:}

Every person who, by or through stock ownership, agency, or otherwise, or who, pursuant to or in connection with an agreement or under- 
should be cognizant of them. This Comment, however, focuses on common law theories because challenges based on these theories, if successful, provide the challenger with the potential to recover punitive damages. Finally, it should be noted that these common law theories are not necessarily mutually exclusive. The differences between several theories, in fact, are far from being clear cut; ${ }^{36}$ significant gray areas exist. Consequently, occasions have arisen in which courts have found against creditors based on several theories of liability falling into several of the categories described above. ${ }^{37}$

\section{A. Improper Acquisition of Control by a Creditor}

The common law torts of fraud, duress, and interference have been a basis for holding creditors liable for improper acquisition of control over debtors. Creditors who gain improper leverage over debtors by making promises with no intention of performing them may be subject to fraud claims. ${ }^{38}$ Examples of such promises include ones to refrain from calling outstanding loans, to extend the maturity of debts, or to make additional advances. In return for these promises, lenders typically receive from debtors additional collateral or consents to other requests.

standing with one or more other persons by or through stock ownership, agency or otherwise, controls any person liable under sections $77 \mathrm{k}$ or 771 of this title, shall also be liable jointly and severally with and to the same extent as such controlled person to any person to whom such controlled person is liable, unless the controlling person had no knowledge of or reasonable ground to believe in the existence of the facts by reason of which the liability of the controlled person is alleged to exist.

15 U.S.C. $\S 770$ (1982).

Section 20:

(a) Joint and several liability; good faith defense.

Every person who, directly or indirectly, controls any person liable under any provision of this chapter or of any rule or regulation thereunder shall also be liable jointly and severally with and to the same extent as such controlled person to any person to whom such controlled person is liable, unless the controlling person acted in good faith and did not directly or indirectly induce the act or acts constituting the violation or cause of action.

15 U.S.C. § 78t (1982).

Those interested in the issue of lender control with regard to securities laws should consult Douglas-Hamilton, supra note 3, at 352-63 and Note, The Controlling Influence Standard in Rule 10b-5 Corporate Mismanagement Cases, 86 HaRv. L. REv. 1007 (1973).

${ }^{38}$ Compare, for instance, the joint venturer, agency, and instrumentality theories discussed infra notes 75-100 and accompanying text.

${ }^{37}$ See, e.g., State Nat'l Bank v. Farah Mfg Co., 678 S.W. 2d 671 (Tex. Ct. App. 1984) (affirming judgment against creditors for fraud, duress, and interference).

${ }_{38}$ See Cappello, supra note 33 , at 4. 
Fraud was alleged by plaintiff stockholders in Stirling $v$. Chemical $B a n k^{3 \theta}$ against nine lenders. The stockholders claimed that the defendant banks had conspired to gain control of the stockholders' corporation through fraud. The banks allegedly represented that they would forebear from calling the debtor corporation's loans and would advance additional sums of money if the plaintiffs would resign their positions as officers and directors of the corporation. The district court agreed that this attempt to reconfigure or otherwise manipulate management, if true, would support a cause of action for common law fraud. ${ }^{40}$

A claim of duress ${ }^{41}$ has been used as an affirmative tort ${ }^{42}$ that, like fraud, can support an allegation that a creditor gained improper control over a debtor corporation or reconfigured that debtor's management. The rationale behind allowing this tort is to discourage or prevent a powerful creditor from presenting an unreasonable choice of alternatives to a debtor in a weaker or more vulnerable bargaining position. ${ }^{43}$ Duress, as it relates to creditor control, encompasses two distinct types of actions by debtors against creditors. ${ }^{44}$ First, duress would lie if the creditor employed extortionate measures to realize its aims. Second, duress may be found if the creditor, lacking good faith, made improper demands to undergird its position. ${ }^{46}$

s9 382 F. Supp. 1146 (S.D.N.Y. 1974), affd, 516 F.2d 1396 (2d Cir. 1975).

${ }^{10} I d$. at 1153 .

11 Duress in this context sometimes is called business or economic compulsion. However, for the sake of consistency the term "duress" will be used throughout this Comment.

${ }^{42}$ See, e.g., Terrel v. Duke City Lumber Co., 86 N.M. 405, 524 P.2d 1021 (N.M. Ct. App. 1974) (holding that fear of economic loss constituted duress and therefore plaintiff was entitled to recover damages); Pecos Constr. Co. v. Mortgage Inv. Co., 80 N.M. 680, 459 P.2d 842 (N.M. 1969) (same); see also Electrical Prods. Co. v. Combined Communications Corp., 535 F. Supp. 356 (D.N.M. 1980) (proper, but unsuccessful, attempt to use duress affirmatively). Most jurisdictions, however, recognize duress not as an affirmative tort, but as a defense used to avoid contractual obligations.

4s See Terrel, at 36 N.M. at 422, 524 P.2d at 1038.

44 See Sanders v. Republic Nat'l Bank, 389 S.W.2d 551 (Tex. Civ. App. 1965).

15 Id. at 554-55. The evidence needed to support this second type of duress allegation also can be used to substantiate a claim that the creditor breached its duty of good faith towards the debtor. The U.C.C. provides that "[e]very contract or duty within this Act imposes an obligation of good faith in its performance or enforcement." U.C.C. $\S 1-203$ (1978). "Good faith" itself is defined as "honesty in fact in the conduct or transaction concerned." Id. at \$1-201(19). Thus, whether or not the creditor has breached his duty of good faith towards the debtor is not dependent on his having actual control over the debtor. Therefore, although a cause of action for duress might not stand in a particular situation, one for "bad faith" still might.

For a current analysis of the relevant court cases pertaining to a lender's duty of good faith, see Weissman, Lender Liability: The Obligation to Act in Good Faith and Deal Fairly, J. Com. Bank Lending, Dec. 1986, at 2. Guidelines instructing lenders on how to avoid liability stemming from a breach of their duty of good faith are found in Heiman and Gordon, Lender Liability: Dodging Bullets with Procedures for Managing Problem Loans, J. Com. Bank Lending, Dec. 1986, at 15. 
Duress, however, is very difficult to establish. Courts, in fact, generally view this tort as a "last resort" to remedy improper control. The court in Rich $\mathcal{E}$ Whillock, Inc. v. Ashton Development, Inc. ${ }^{46}$ in addition to highlighting the relationship between duress and the duty of good faith, emphasized this point:

The underlying concern of the economic duress doctrine is the enforcement in the marketplace of certain minimal standards of business ethics. . . . [The common rules of our economic system] include equitable notions of fairness and propriety which preclude the wrongful exploitation of business exigencies to obtain disproportionate exchanges of value. Such exchanges make a mockery of freedom of contract and undermine the proper functioning of our economic system. The economic duress doctrine serves as a last resort to correct these aberrations when conventional alternatives and remedies are unavailing. ${ }^{47}$

Consequently, the tort of duress is only infrequently asserted as the primary claim of a debtor against its creditor for the improper seizure of control. ${ }^{48}$

48157 Cal. App. 3d 1154, 204 Cal. Rptr. 86 (1984). The plaintiff in this case had billed the defendant in the amount of $\$ 72,000$; however, the defendant refused to pay the total sum but instead countered with an offer to pay $\$ 50,000$ in full settlement of its obligation. Since the plaintiff was faced with financial disaster if it refused to accept this "take it or leave it" offer, it accepted the lesser sum and released the defendant from its total obligation. The court, however, would not allow such a result, finding that the plaintiff's release of the defendant was not enforceable since it had been obtained through economic duress. Id. at 1160-61, 204 Cal. Rptr. at 90-91.

17 Id. at 1159, 204 Cal. Rptr. at 89-90.

48 Especially problematic from the debtor's point of view is determining whether or not its creditor is engaged in simple "hard bargaining" or actions giving rise to duress. The inapplicability of duress when "hard bargaining" is involved is discussed in Continental Ill. Nat'l Bank \& Trust Co. v. Stanley, 606 F. Supp. 558 (N.D. Ill. 1985). Continental brought an action for itself and also as an agent for thirteen other banks against Stanley to recover on Stanley's personal guarantee of loans made by the banks to several operations controlled by Stanley. Stanley countered by alleging numerous acts of misconduct by Continental: failure to extend new credit to the borrowers on occasion; failure to extend credit on terms and conditions acceptable to the borrowers at times when such credit was made available; exercise of broad powers via an agent in a manner that the borrowers felt was undesirable; and the bank's failure to mitigate damages. Id. at 562 .

The district court found that the defendant's allegations of economic duress were not supported by any of the defendant's affidavits or other proof. The defendant had alleged duress claiming that the plaintiff banks threatened imminent bankruptcy of the four companies controlled by him through a credit cutoff if the individual defendant did not sign a personal guarantee. Id. The court, however, disagreed, finding that the plaintiff's actions did not constitute duress since the defendant's personal guarantee merely was secured either as a result of hard bargaining or the pressure of financial conditions. It emphasized that in cases in which agreements have been invalidated on 
Debtors often have alleged interference on the part of creditors when the latter group has improperly gained control over them. ${ }^{48}$ Interference claims in the creditor control context normally allege one of two things: either that the creditor interfered with the governance of the debtor corporation or with that corporation's current or prospective contractual relations with third parties.

Interference with corporate governance occurs when the creditor uses its authority over the debtor to prevent the debtor's board of directors from properly conducting its duties, ${ }^{\text {Do }}$ often at the expense of the debtor's financial health. For example, the debtor may claim that the acts of the creditor in selecting board members or management interfered with its statutory governance rights by disrupting formal corporate election procedures. ${ }^{51}$ Often, however, the debtor's claim is one

grounds of duress, the conduct of the party obtaining the advantage was tainted with some degree of fraud or wrongdoing. This "taint," the court determined, was not present in the case before it. Id.

to See, e.g., Melamed v. Lake County Nat'l Bank, 727 F.2d 1399 (6th Cir. 1984) (plaintiff stated cause of action for interference where creditor gained unwarranted control over debtor's management and operations).

so Normally, a corporation's board of directors is charged with the duty to manage and direct the corporation's endeavors. See H. HenN \& J. Alexander, Laws of Corporations and Other Business Enterprises $\S 207$ (3d ed. 1983). Some delegation of the board's duties, however, is possible. See Note, Delegation of Duties by Corporate Directors, 47 VA. L. REv. 278 (1961); Comment, Delegating the Managerial Functions of Corporate Directors, 5 S. TEx. L.J. 293 (1960). But directors cannot delegate all of their rights to manage the enterprise. See Sherman \& Ellis, Inc. v. Indiana Mut. Casualty Co., 41 F.2d 588, 590 (7th Cir. 1930); H. Henn \& J. AlexanDER, supra at $\S 212$.

s1 See, e.g., State Nat'I Bank v. Farah Mfg. Co., Inc., 678 S.W.2d 661 (Tex. Ct. App. 1984). The Court of Appeals of Texas affirmed the jury's verdict that the creditors had committed the torts of fraud, duress, and interference. The specific acts of interference committed by the creditors included: (1) compelling the resignation of $W$. Farah and his supporters from the board while preventing the election of any further W. Farah supporters to the board; (2) placing a lenders' representative in the position of chairman of the board; (3) ensuring that the board was filled with lender supporters; (4) encouraging and financially supporting litigation in a proxy fight against W. Farah when he sought to bring back governance power into the hands of the corporation. In referring to the interference claims involving corporate governance, the court stated:

[The debtor corporation] was entitled to have its affairs managed by competent directors and officers who would maintain a high degree of undivided loyalty to the company.

The evidence is factually sufficient that the [creditors'] interference compelled the election of directors and officers whose particular business judgment and inexperience and whose divided loyalty proximately resulted in injury to the [corporate debtor].

678 S.W.2d at 690. But see Flintridge Station Assocs. v. American Fletcher Mortgage Co., 761 F.2d 434 (7th Cir. 1985). Here, the court held that the defendant mortgage company could properly request its debtor to disassociate itself from an individual where the evidence showed that many of the difficulties encountered by the debtor were traceable to that person. The court added that generally "[a] lender has a legitimate 
that the creditor simply abrogated the independent decisionmaking authority of the directors. ${ }^{52}$

Tortious interference with the current contractual relations between the debtor and third parties, on the other hand, depends on the existence of either a valid contract or, at a minimum, a prospective economic relationship. ${ }^{53}$ In addition, knowledge by the defendant, intent to interfere, proximate cause, and damages must be proven by the plaintiff. ${ }^{\delta 4}$ While most suits alleging interference with contractual relations are brought by third parties, such as disgruntled corporate officers upon termination, ${ }^{\mathrm{BS}}$ rather than the debtor itself, this is not always the case. $^{\mathrm{sB}}$ Tortious interference with contractual relations is particularly difficult to prove because it is heavily fact-specific ${ }^{57}$ and also subject to

concern in the management of its borrowers." 761 F.2d. at 442.

${ }_{52}$ See, e.g., Walton Motor Sales v. Ross, 736 F.2d 1449 (11th Cir. 1984). In this case the debtor had signed an agreement that gave the secured creditor "full, absolute, and complete control" over the debtor's credit policies and other fiscal affairs. The contract further provided that the secured creditor could take possession of all the corporate debtor's property in the event of a default. When addressing this contract, the court noted that such a contract normally would be void, since it divested the corporate directors of their authority and discretion to formulate corporate policy. Id. at 1457. However, the court allowed the contract to stand in this case, due to a state statute that made it lawful for shareholders of closely-held corporations, who also doubled as the directors and officers of the corporation, to divest themselves of control in the manner dictated by the contract. Id. at 1147-58.

${ }^{63}$ See Buckaloo v. Johnson, 14 Cal. 3d 815, 822-23, 537 P.2d 865, 868-69, 122 Cal. Rptr. 745, 748-49 (1975) (discussing tortious interference in the real estate brokerage context).

${ }_{84}$ See Lipman v. Brisbane Elementary School Dist., 55 Cal. 2d 224, 359 P.2d 465, 11 Cal. Rptr. 97 (1961) (stating that proximate cause and damages are elements of plaintiff's prima facie case for tortious interference).

os See, e.g., Del State Bank v. Salmon, 548 P.2d 1024 (Okla. 1976) (defendant, former president of borrower, unsuccessfully counterclaimed tortious interference with his employment by the lender).

${ }^{s 8}$ See, e.g., Flintridge Station Associates v. American Fletcher Mortgage Co., 761 F.2d 434 (7th Cir. 1985) (plaintiff borrower alleged that defendant interfered with the borrower's contract with a permanent lender and told plaintiff's tenants to pay their rent directly to the lender contrary to the tenants' rental agreements).

Restatement:

s7 See Restatement (Second) OF TorTS \$767 (1981). According to the

In determining whether an actor's conduct is intentionally interfering with a contract or a prospective contractual relation of another is improper or not, consideration is given to the following factors:

(a) the nature of the actor's conduct,

(b) the actor's motive,

(c) the interests of the other with which the actor's conduct interferes,

(d) the interests sought to be advanced by the actor,

(e) the social interests in protecting the freedom of action of the actor and the contractual interests of the other,

(f) the proximity or remoteness of the actor's conduct to the interference and 
several potent defenses available to the defendants, such as "business justification" or a "proper assertion of a bona fide claim."

\section{B. Subsequent Abuse of Legitimately Acquired Control}

Creditors also may find their actions towards their debtors challenged not because those actions amounted to improper acquisition of control, as in the preceding section, but because of a subsequent abuse of control previousiy gained through legitimate means. Two common law tort theories have been employed in this regard. The first one, fraud, is also important in the context of improper acquisition of control by a creditor. The second one, which is solely concerned with abuse of legitimate power, encompasses breaches of fiduciary responsibilities by creditors.

A vivid example of creditors abusing legitimate power via acts of fraud is portrayed in State National Bank of El Paso v. Farah Manu-

(g) the relations between the parties.

See also Herran v. State Farm Mut. Ins., 56 Cal. 2d 202, 206, 363 P.2d 310, 362, 14 Cal. Rptr. 294, 296 (1961) (listing factors to consider when determining whether an intentional interference by a third party is justifiable).

${ }_{88}$ For the business justification defense, see Restatement (SECOND) of TORTS, supra note 57 , at $\$ 769$, which states:

One who, having a financial interest in the business of a third person, intentionally causes that person not to enter into a prospective contractual relation with another, does not interfere improperly with the other's relation if he:

(a) does not employ wrongful means and

(b) acts to protect his interest from being prejudiced by the relation.

See also Bridges v. Cal-Pacific Leasing Co., 16 Cal. App. 3d 118, 93 Cal. Rptr. 796 (1971) (defendant allowed to induce lessee to breach lease so long as he acts solely to protect his financial interest and not to harm the lessor); Del State Bank, 548 P.2d at 1027 ("Evidence was sufficient to sustain a finding that the bank's acts were designed to benefit the bank. . . . Its economic power was used to . . . better its financial position ... [and] not to wrongfully harm [the plaintiff], though the acts were to [plaintiff's] detriment.").

For the bona fide claim defense, see Restatement (Second) of ToRTs, supra note 57 , at $\S 773$, which states:

One who, by asserting in good faith a legally protected interest of his own or threatening in good faith to protect the interest by appropriate means, intentionally causes a third person not to perform an existing contract or enter into a prospective contractual relation with another does not interfere improperly with the other's relation if the actor believes that his interest may otherwise be impaired or destroyed by the performance of the contract or transaction.

See also Kelly v. International Harvester Co., 278 N.C. 153, 179 S.E.2d 396 (1971) (defendant was allowed to threaten termination of a franchise agreement if the plaintiff was not discharged since the franchise agreement gave the defendant a bona fide right to terminate the agreement if there was a change in the management of the dealer). 
facturing Company, Inc. ${ }^{59}$ In this case, defendant bank and other lenders perpetrated fraud against the Farah Manufacturing Company (Farah) through the use of false threats. The lenders implicitly threatened to declare default on Farah's indebtedness to them, which, in turn, would drive the debtor corporation into bankruptcy. ${ }^{60}$ The purpose behind the threats, which were made to members of Farah's board of directors and its former chief executive officer, was to prevent the former CEO from being reinstated as head of the corporation. ${ }^{61}$ But under a management change clause in the debt instrument, a control device legitimately acquiesced to by Farah, the creditors could either call the loan if unacceptable management took over or forego calling the loan and live with the debtor board's decision. ${ }^{62}$ The creditors, however, chose to follow neither course and instead attempted to prevent outright the desired change in management by use of threats. This constituted an abuse of the management change clause, and accordingly, the jury found against the creditors. ${ }^{63}$

Lenders also can abuse legitimately acquired control through a breach of their fiduciary responsibilities, if any, towards their debtors. ${ }^{64}$ The "if any" qualification is important, since case law currently acknowledges that the normal relationship between a lender and its debtor is not a fiduciary relationship. ${ }^{60}$ Furthermore, the mere render-

s9 678 S.W.2d 661 (Tex. Ct. App. 1984); see also supra note 51 and accompanying text.

Bo State Nat'l Bank, 678 S.W.2d at 668 .

61 Id.

62 Id.

6s See id. at 680-82 (discussing and affirming the jury's finding).

o4 Financial institutions are also vulnerable to attack for having assisted others in breaching their fiduciary duties. In order to show that the creditor induced or participated in such a breach, however, a claimant must prove: (1) that a fiduciary breached obligations to a third party; (2) that the ereditor knowingly induced or participated in the breach; and (3) that a third party suffered damages as a result of the breach. See Whitney v. Citibank, N.A., 782 F.2d 1106, 1115 (2d Cir. 1986); Newburger, Loeb \& Co. v. Gross, 563 F.2d 1057, 1074 (2d Cir. 1977), cert. denied, 434 U.S. 1035 (1978).

In Whitney, the court affirmed a trial court verdict against the lender based upon allegations that it had knowingly induced two of the three general partners of a New York general partnership to breach their duty to the partnership and to the third general partner. The bank was found not only to have induced the breach but also to have actively participated in it by giving the consent of the partnership to a deed in lieu of foreclosure which related to real property. This consent was provided without any consideration to the partnership, without the third partner's knowledge, and without regard to the provisions found in the partnership agreement. The court determined that the bank acted in this way in an effort to deceive the general partners and earn a profit for the bank and a favored customer on the sale of the subject property. The court, therefore, upheld the award against Citibank for general damages of $\$ 236,677$ and for punitive damages of $\$ 1,500,000$. 782 F.2d at 1117-19.

es See Aaron Ferer \& Sons, Ltd. v. Chase Manhattan Bank, N.A., 731 F.2d 112, 122 (2d Cir. 1984) (stating that New York law recognizes the usual relationship be- 
ing of advice or counseling by a financial institution normally is insufficient to establish such a relationship; ${ }^{66}$ more is needed. ${ }^{67} \mathrm{~A}$ fiduciary relationship, for example, may arise out of an informed relationship in which both parties clearly understand that a special trust or confidence has been established. ${ }^{68}$ Consequently, if a creditor were to take advantage of this special trust at its debtor's expense, a claim would lie based on the creditor's abuse of its fiduciary duties.

tween a bank and its customer as that of debtor and creditor, not a fiduciary one). But see Cappello, supra note 33, at 6. He cites the recent case of Commercial Cotton Co. v. United California Bank, 163 Cal. App. 3d 511, 516, 209 Cal. Rptr. 551, 554 (1985), which states that in California the relationship between a bank and its depositor is at least quasi-fiduciary, to suggest that "the day when a bank's relationship to its borrower is held to be fiduciary may not be far away."

${ }^{86}$ See Stenberg v. Northwestern Nat'l Bank, 307 Minn. 487, 488, 238 N.W.2d 218 (1976) (creditor's advice to debtor regarding the procurement of a Small Business Administration loan with which to consolidate and reduce debt to creditor did not create fiduciary duty where the debtor possessed years of experience and exercised independent judgment).

67 See Douglas-Hamilton, supra note 3, at 352. She states:

Where the creditor controls the corporate debtor by voting control of its stock, dominant influence in its management or ability otherwise to control its business affairs, the creditor may have a fiduciary duty to its corporate debtor. Fiduciaries' transactions with a beneficiary are subject to rigorous scrutiny. The burden is on the creditor who is a fiduciary to prove good faith and fairness to the corporation and its beneficiaries in any transaction with the corporation in which such creditor is involved.

68 See Deist v. Wachholz, 678 P.2d 188, 193-94 (Mont. 1984); Umbaugh Pole Bldg. Co. v. Scott, 58 Ohio St. 2d. 282, 390 N.E.2d 320, 323 (1979); see also Klein v. First Edina Nat'l Bank, 293 Minn. 418, 196 N.W.2d 619 (1972) (fiduciary duty only arises when special knowledge regarding customers' expectations is known by the creditor).

In Deist, a widow ("Deist") sold her ranch to one Dittman, who purchased as a trustee. Soon afterwards, Deist discovered that Dittman had bought on behalf of a partnership that included Dittman and Wachholz, a vice-president of the Conrad $\mathrm{Na}$ tional Bank. The bank had a long standing relationship with the Deist family. In fact, Gillette, the bank's president, was a close family friend and advisor. When Deist learned who was involved in the partnership, she became upset and sought rescission of the contract based on a variety of grounds, including breach of fiduciary duty. The trial court allowed rescission of the contract based upon Wachholz' breach of his fiduciary duty to Deist.

In affirming the lower court's decision, the appellate court noted that substantial evidence existed that the relationship between Deist and the bank was much more than the simple creditor-debtor relationship. Indeed, Deist and her husband had dealt with the bank for 24 years and had placed special trust and confidence in the bank's president, who had been acting as Deist's financial advisor after her husband's death with respect to the handling of the ranch indebtedness. Any fiduciary duty vested in one officer of the bank carried over to any bank officer involved in the transaction, including Wachholz. Wachholz, therefore, had a duty to inform Deist fully as to his involvement in the ranch purchase and to not take unfair advantage of Deist. 678 P.2d at 19495. 


\section{Excessive Involvement of a Creditor with Its Debtor}

The preceding two sections have focused on the issue of control itself and, in particular, how a creditor first procures it and subsequently uses it. The third category of control liability, however, addresses the degree of a creditor's involvement in its debtor's affairs. Such entanglement comes in many forms:

Frequently, in order to protect its interests, a creditor comes to the aid of a struggling debtor and provides a variety of services to assist the operation of the debtor's business, such as managing payables and receivables, providing technical expertise in manufacturing processes or offering guidance on the retention and dismissal of personnel. The list can be as extensive as there are distressed debtors. ${ }^{68}$

Too much involvement, however, may open a creditor up to accusations that it is excessively controlling its debtor. Third parties, such as competing creditors, not the debtor itself, usually make these accusations, claiming that they were damaged in some way through their interactions with the controlled debtor. ${ }^{70}$ They allege that, because the controlling creditor was so involved in the debtor's affairs, holding the creditor accountable for the debtor's actions would be equitable. ${ }^{71}$ Third parties looking to hold the controlling creditor liable for the controlled debtor's obligations usually employ one or more of the following arguments: that the creditor was (1) a joint venturer with its debtor, ${ }^{\mathbf{2}}$ (2) a principal with its debtor as agent, ${ }^{73}$ or (3) a controlling entity with its debtor operating merely as its instrument. ${ }^{74}$

In order to hold a creditor liable under a joint venturer theory, the

${ }^{60}$ Lundgren, supra note 4, at 549.

${ }^{70}$ See e.g., Krivo Indus. Supply Co. v. National Distillers \& Chem. Corp., 483 F.2d 1098 (5th Cir. 1973) (action by ten creditors against debtor's major creditor based on latter's domination of debtor); A. Gay Jenson Farms Co. v. Cargill, Inc., 309 N.W.2d 285 (Minn. 1981) (action by farmers against a corporation which controlled a local grain elevator that defaulted on contracts with farmers); see also Dunson v. Stockton, Whatley, Davin \& Co., 346 So. 2d 603 (Fla. Dist. Ct. App. 1977) (counterclaim by mortgagor in a foreclosure action based on control of a construction company, with whom mortgagor contracted to build a house, by the mortgagee); Connor v. Great W. Sav. \& Loan Ass'n, 69 Cal. 2d 850, 447 P.2d 609; 73 Cal. Rptr. 369 (1968) (action by purchasers of single family homes against Savings and Loan Association which allegedly engaged in joint venture with developer).

${ }_{71}$ See Krivo, 483 F.2d at 1101, 1106-07 (The alleged liability was predicated on the equitable principle that the dominant corporation should be responsible for the debts of the subservient "instrumentality.").

72 See infra notes 75-81 and accompanying text.

73 See infra notes 82-88 and accompanying text.

74 See infra notes 89-100 and accompanying text. 
claimant must establish the requisite collusion between the creditor and debtor by showing three things: the existence of an express or implied contractual relationship between the parties, a sharing of profits and losses, and a combination of property, skill, or knowledge. ${ }^{75}$ While the absence of one of these elements is not always fatal, ${ }^{76}$ the existence of contractual relations pertaining to the sharing of profits and losses is treated by many courts as a sine qua non. ${ }^{77}$ On the other hand, actual joint control over the endeavor, while needed, does not necessarily mean mutual control over every aspect of the venture. Courts have interpreted joint control to include an allocation of decisionmaking in line with the particular abilities of each co-venturer. ${ }^{78}$

The results of challenges to creditor involvement based on the "joint venturer" theory have been unencouraging at best. ${ }^{79}$ The main obstacle to successful litigation has been the inability of third parties to

7s See McGhan v. Ebersol, 608 F. Supp. 277, 282 (S.D.N.Y. 1985) (restating the three requirements for proving existence of a joint venture).

${ }^{78}$ See Thomas, Inc. v. Stanhope St. Associates (In re Thomas, Inc.), 37 Bankr. 387, 391 (Bankr. D. Mass, 1984) (all parties to the joint venture need not hold property titles in common, although a joint property interest is a factor bearing on whether a joint venture exists).

${ }^{77}$ See Mallis v. Bankers Trust Co., 717 F.2d 683, 690 (2d Cir. 1983) ("Under New York law, the crucial element of a joint venture is the existence of 'a mutual promise or undertaking ...." "); Missouri-Indiana Inv. Group v. Shaw, 699 F.2d 952, 958 (8th Cir. 1983) ("Joint ventures arise from contractual relations, but may be established without specific formal agreement and may be implied or proved by facts and circumstances."); McGhan, 608 F. Supp. at 282 (" "An agreement between the parties to create a joint adventure is essential . . . . (citation omitted)); Institutional Management Corp. v. Translation Sys., Inc., 456 F. Supp. 661, 665 (D. Md. 1978) ("Joint adventures never arise by operation of law, but must arise from a form of contract.").

${ }^{78}$ See Lions Corp. v. PCH Assocs. (In re PCH Assocs.) 60 Bankr. 870, 876 (Bankr. S.D.N.Y.) affd, 504 F.2d 193 (2d Gir. 1986) (joint venture may be inferred from documents outlining particular allocations of duties and responsibilities, a condition that satisfied requirement of joint proprietorship and mutual control over the subject matter); Halloran v. Ohlmeyer Communications Co., 618 F. Supp. 1214, 1219 (S.D.N.Y. 1985) (division of responsibilities based on separate areas of expertise will not bar a finding that a joint venture existed).

${ }_{79}$ See, e.g., Connor v. Great W. Sav. \& Loan Ass'n, 69 Cal. 2d 850, 447 P.2d 609, 73 Cal. Rptr. 369 (1968). In Connor, the Supreme Court of California refused to find that the defendant, a financial institution, and a construction contractor engaged in a joint venture. Instead, the court choose to find the lender liable in tort for breaching a broadly construed duty of care. The court's language underscores the difficulty of showing the existence of a joint venture:

Although the evidence establishes that [the lender] and [the contractor] combined their property, skill, and knowledge to carry out the tract development, that each shared in the control of the development, that each anticipated receiving substantial profits therefrom, and that they cooperated with each other in the development, there is no evidence of a community or joint interest in the undertaking. . . . [N]o joint venture existed.

Id. at 863,447 P.2d at 615,73 Cal. Rptr. at 375. 
prove the existence of the requisite contractual agreement between the parties to share in both the profits and the losses stemming from their joint venture. Indeed, this sharing of profits and losses has been held to mean more than the creditor simply receiving or not receiving the principal and interest from its loan. ${ }^{80}$ In addition, the fact that the creditor provides financing to the debtor's customers with which to purchase the debtor's products is not dispositive as to the existence of a joint venture $^{81}$ Consequently, the "joint adventurer" theory has not proven to be very effective as a weapon with which third parties can impose liability on a controlling creditor for the obligations of that creditor's debtor.

A lender who aggressively interacts with its debtor may face challenges to that involvement based on an agency theory. The feature that distinguishes the agency theory from the joint venturer theory is the requirement of an understanding between the parties that the agent is to act primarily for the benefit of the principal. ${ }^{82}$ The sharing of profits is not contemplated. Successful challenges will result in the creditor being held responsible for all of its debtor's business obligations. ${ }^{83}$ Generally, for an agency relationship to arise, the principal must agree that the agent can act on the former's behalf, and the agent must then act subject to the principal's direction and control..$^{84}$ Importantly, the way in which the parties choose to characterize their relationship is not controlling. ${ }^{85}$

so See Atlanta Shipping Corp. v. Chemical Bank, 631 F. Supp. 335, 351 (S.D.N.Y. 1986) (requirement that profits and losses be shared cannot be satisfied if the lender has contracted for only a limited share of potential losses).

81 See Satellite Fin. Planning Corp. v. First Nat'l Bank, 633 F. Supp. 386, 401 (D. Del. 1986) (financing provision not adequate condition for finding a joint venture, especially where state partnership law requires additional conditions, such as control).

${ }^{82}$ See Westinghouse Elec. Corp. v. Rio Algom Ltd., 448 F. Supp. 1284, 1301 (N.D. Ill.), affd in part and reversed in part on other grounds, 580 F.2d 1311 (7th Cir.), rev'd on other grounds, 588 F.2d 221 (7th Cir.), cert. denied, 439 U.S. 955 (1978); Restatement (Second) OF Agency §§ 1, 13, 13 comment b (1958).

${ }^{83}$ See Kunkel, supra note 4, at 468-71.

84 See Pan Am. World Airways, Inc. v. Shulman Transp. Enters. (In re Shulman Transp. Enters., Inc.), 744 F.2d 293, 295 (2d Cir. 1984) (stating that in a bankruptcy suit, a court must look at the substance of the relationship between the creditor, the debtor, and the alleged principal: "An essential element of an agency relationship is that the agent acts subject to the principal's direction and control."); Southern Pac. Transp. Co. v. Continental Shippers Ass'n, Inc., 642 F.2d 236, 238 (8th Cir. 1981) (finding an agency relationship where principal had granted actual authority and then controlled the agent's activities on behalf of the principal, in addition to the agent having accepted to undertake these activities for the principal).

${ }_{85}$ See Northern v. McGraw-Edison Co., 542 F.2d 1336, 1343 n.7 (8th Cir. 1976), cert. denied, 429 U.S. 1097 (1977) ("If the surrounding facts evidence an agency relationship, however 'artfully disguised', the parties cannot negative its existence by representing that it is something other than an agency relationship."). 
The Restatement of Agency provides guidance to the courts when faced specifically with a challenge to a creditor's excessive involvement: "A creditor who assumes control of his debtor's business for the mutual benefit of himself and his debtor, may become a principal, with liability for the acts and transactions of the debtor in connection with the business." ${ }^{\text {"8s }}$ Further guidance is found in the comments: "The point at which the creditor becomes a principal is that at which he assumes de facto control over the conduct of his debtor, whatever the terms of the formal contract with his debtor may be." cumstantial evidence when attempting to impose liability upon a creditor for the acts of its debtor. This includes the parties' situations relative to one another, their actions taken towards themselves and third parties, and other relevant circumstances needed to show that the debtor had "apparent authority" to bind the creditor. ${ }^{88}$

86 Restatement (Second) of Agency, supra note 82, at $\$ 14 \mathrm{O}$.

${ }^{87}$ Id. at comment a. This comment also offers an example of the types of control to be considered in determining creditor liability:

A security holder who merely exercises a veto power over the business acts of his debtor by preventing purchases or sales above specified amounts does not thereby become a principal. However, if he takes over the management of the debtor's business either in person or through an agent, and directs what contracts may or may not be made, he becomes a principal, liable as any principal for the obligations incurred thereafter in the normal course of business by the debtor who has now become his general agent.

Id. Lundgren argues that the direction given by comment a, however, may be at odds with $\S 14 \mathrm{O}$ : "It is difficult to harmonize the comment with section $14 \mathrm{O}$. The comment suggests a test for imposing liability similar to that used in the instrumentality cases, while section $14 \mathrm{O}$ appears to envision a broader standard for imposing liability which will be more readily satisfied." Lundgren, supra note 4, at $536 \mathrm{n} .62$; see also infra notes 89-100 and accompanying text (containing discussion of instrumentality doctrine). Kunkel adds impliedly that the courts may be using a stricter standard than the one offered by the Restatement. He suggests that the courts are requiring that the creditor actually must have kept the debtor in existence to further the creditor's own purposes in addition to satisfying the requirements of the Restatement. See Kunkel, supra note 4 , at 471 .

${ }_{88}^{83}$ See In re Atlantic Fin. Management, Inc., 784 F.2d 29, 31-32 (1st Cir. 1986); Prudential Ins. Co. of Am. v. Curt Bullock Builders, Inc., 626 F. Supp. 159, 166 (N.D. Ill. 1985); A. Gay Jenson Farms Co. v. Cargill, Inc., 309 N.W.2d 285, 291-93 (Minn. 1981).

The key case in this area, Cargill, arose out of the financial demise of a grain elevator business, Warren Grain \& Seed Co. (Warren), in Minnesota. Attorneys representing eighty-six farmers successfully argued that liability should attach to the defendant Cargill, Inc., a lender to Warren. They based their arguments upon an actual agency theory and recovered Warren's indebtedness to the plaintiff-farmers for $\$ 2,000,000$. Id. at 289-90. The Minnesota Supreme Court, in affirming the jury's verdict, stated:

By directing Warren to implement its recommendations, Cargill manifested its consent that Warren would be its agent. Warren acted on Cargill's behalf in procuring grain for Cargill as the part of its normal opera- 
A third type of challenge to excessive creditor involvement makes use of the instrumentality, or "alter ego," theory of liability. Successful challenges allow third parties to collect against controlling parties for the obligations of their subservients. ${ }^{89}$ When applying this theory to the facts of a case, courts concern themselves with the reality, not the formality, of the relationship between the controlling and subservient parties, and focus on the autonomy displayed by the subservient. ${ }^{90}$ In the lender liability context, a creditor will be held liable if it is found to have exercised the requisite quantum of control over the debtor in such a way as to proximately harm a third party. ${ }^{91}$ The rationale for imposing liability is that, since the creditor has misused the debtor's corporate

tions which were totally financed by Cargill. Further, an agency relationship was established by Cargill's interference with the internal affairs of Warren, which constituted de facto control of the elevator.

Id. at 291. The court pointed to numerous factors to support its finding that Cargill, indeed, had become a principal and thus responsible for the transactions entered into by its agent Warren: (1) Cargill's constant recommendations to Warren by telephone; (2) Cargill's right of first refusal on Warren's grain; (3) Cargill's power to restrict Warren's ability to enter into mortgages, purchase stock, or pay dividends by means of withholding its permission; (4) Cargill's right of entry onto Warren's premises coupled with its right to conduct periodic checks and audits on Warren's operations; (5) Cargill's criticism of Warren's finances, officers' salaries, and level of inventory; (6) Cargill's determination that Warren needed very "strong paternal guidance"; (7) Warren's forms and drafts upon which Cargill's name was imprinted; (8) Cargill's financing of all of Warren's grain purchases and operating expenses; and (9) Cargill's ability to discontinue the financing of Warren's operations. Id.

Even more important was the Court's dismissal of Cargill's claim that the factors above were to be found in most common debtor-creditor relationships. The court responded by stating that, although this might normally be the case, these factors must be viewed in light of Cargill's "aggressive financing" policy towards Warren. Id. Moreover, the court further determined that Cargill had directed Warren's actions not to make money as a lender but to "ke[ep] Warren in existence" for its own purposes. Id. at 293. If Cargill had interacted with Warren in order to assist it with general plans designed to aid all who had an interest in the debtor, then liability as a principal may not have attached. See Kunkel, supra note 4, at 471 . In his analysis of the case, Kunkel stresses the court's finding that Cargill simply did not seek to protect its interests, but instead kept the debtor going to further its own interests.

${ }_{89}$ See Baker v. Raymond Int'l, Inc., 656 F.2d 173, 179 (5th Cir. 1981), cert. denied, 456 U.S. 983 (1982) (stating that controlling parties are liable for obligations of subservient corporations that are totally dominated and have no separate interests or functions); FMC Fin. Corp. v. Murphree, 632 F.2d 413, 421-22 (5th Cir. 1980) (in deciding whether to pierce the corporate veil, jury should consider control of subsidiary by parent and misrepresentation made to obscure relationship of the entities).

${ }_{80}$ See DeWitt Truck Brokers, Inc., v. W. Ray Flemming Fruit Co., 540 F.2d 681, 685 (4th Cir. 1976) (in piercing the corporate veil, the court highlighted need to focus on factual realities, including the manner in which the corporation operated, and the individual defendant's relationship to that operation).

91 See Krivo Indus. Supply Co. v. National Distillers \& Chem. Corp., 483 F.2d 1098, 1102-03 (5th Cir. 1973), modified and petition for reh'g denied, 490 F.2d 916 (5th Cir. 1974) (in appeal of decision to hold one party liable for the debts of another, the court will act so as "to affix liability where it justly belongs," regardless of the formality of separate corporate entities). 
form in order to further its own purposes, the obligations of the debtor are in reality those of the controlling creditor. ${ }^{\mathbf{9 2}}$

The instrumentality theory differs from the preceding two theories because it requires that the creditor exhibit total control over the debtor, that the debtor maintain no separate corporate purpose whatsoever, and that fraud or inequity flow from the creditor's excessive involvement. ${ }^{93}$ Total control means just that: "actual, participatory, [and] total control of the debtor," not merely a controlling influence. ${ }^{94}$ Courts have looked to the following factors in determining whether the requisite control exists: ownership of or voting rights in the debtor's stock, the commonality of officers and directors between the two parties, the degree to which the controlling party provides financing to the subservient party, and the role that the controlling party plays in the subservient party's operations. ${ }^{95}$ The degree of control needed to substantiate an instrumentality or alter ego claim, however, is difficult to prove. Indeed, the courts have been extremely reluctant to impose liability based on this theory. ${ }^{98}$

The recent case of James E. McFadden, Inc. v. Baltimore Contractors, Inc. ${ }^{97}$ exemplifies the difficulty of proving the requisite degree of control needed to establish instrumentality liability. In this case a subcontractor ("sub") sought to impose liability on the major creditor of its general contractor ("general") based on the general's failure to make payments to the sub. The sub alleged that the lending agreement between the creditor and the general, in addition to other factors, ${ }^{98}$

92 Id. at 1102 .

9s See James E. McFadden, Inc. v. Baltimore Contractors, Inc., 609 F. Supp. $1102,1105,1107$ (E.D. Pa. 1985).

Krivo, 483 F.2d at 1105.

${ }^{85}$ See id. at 1103-06; Japan Petroleum Co. v. Ashland Oil, Inc., 456 F. Supp. 831, 841 (D. Del. 1978).

${ }^{86}$ See Lundgren, supra note 4, at 533. Lundgren further states:

It appears from the decisions that courts recognize the practical necessities that arise when creditors are confronted with debtors in financial distress. ... [U]nder the instrumentality rule courts permit a creditor to place itself in a position to obtain all necessary information, to request a negative veto power over a debtor's financial transactions and to provide assistance or counseling to a debtor. There is a stronger likelihood that liability will be imposed under this rule when a creditor demands and assumes such control over the entire spectrum of a debtor's business affairs that existing management is supplanted and is reduced to carrying out the directions of the creditor. It is, however, difficult to define the precise point at which liability will attach in view of the relatively small number of cases that have applied the instrumentality rule to the debtor-creditor relationship.

Id. at 533-34 (footnotes omitted).

${ }^{87} 609$ F. Supp. 1102 (E.D. Pa. 1985).

${ }^{98}$ These included interoffice memoranda of the creditor, which allegedly sup- 
caused the general to become the creditor's instrumentality. ${ }^{90}$ Therefore, the sub argued, the creditor should make good on the general's obligations. The court, however, disagreed. It characterized the agreement as not providing the creditor with the requisite "absolute control" over the debtor. The control provided by the agreement, according to the court, only helped the creditor to minimize its credit risk. With regard to the other control factors, the court viewed them as either irrelevant or too tangential to substantiate actual and total control. ${ }^{\mathbf{1 0 0}}$

\section{Controlling Greditors as Controlling Shareholders}

In light of the preceding section, it is no wonder that financial institutions and other creditors remain somewhat perplexed as to exactly what degree and type of control they may exert legally over their debtors to protect their investments. The purpose of this section is to clarify the control issue by analyzing it in light of fundamental corporate law principles. In particular, the focal point will be the similarities between the relationship of a controlling shareholder ${ }^{101}$ and her corporation and that of a controlling creditor and its debtor.

This section serves two purposes. First, the insights gained from the analysis provide courts grappling with the creditor control issue additional justification for imposing liability on creditors in certain circumstances. Second, the analysis highlights particular situations that creditors should avoid in order to reduce the likelihood of successful challenges to their control. Consequently, both legitimacy in judicial

ported the view that the creditor controlled the general, and the creditor's right to refuse to bond new contracts unless a new and acceptable chief executive officer was brought on board to run the general. Id. at 1107-09.

99 The lending agreement contained over fourteen conditions that, if not observed, could result in the creditor terminating further bonding of the general and/or foreclosing on its loan. These conditions, which to a layperson would appear to have provided the creditor with broad-based control over the general, detailed requirements of reporting, authorization, and general operations. Id. at 1103-04.

100 See id. at 1108-09.

101 References to "controlling" shareholders within this Comment encompass the terms "majority" and "dominating" shareholders, in that these shareholders have been deemed to owe fiduciary obligations to the corporation. See Drobbin v. Nicolet Instrument Corp., 631 F. Supp. 860, 899 (S.D.N.Y. 1986); First Nat'l Bank of Boston v. Overmyer (In re Overmyer), 53 Bankr. 952, 957 (Bankr. S.D.N.Y. 1985). This stems from the fact that ownership of more than $50 \%$ of the voting stock is not crucial to the imposition of such duties. Drobbin, $631 \mathrm{~F}$. Supp. at 899 . The key is whether the particular shareholder or shareholders have actual control of the corporation. See Lewis v. Knutson, 699 F.2d 230, 235 (5th Cir. 1983); Note, The Fiduciary Duty of Controlling Shareholders, 7 W. RESERve L. REV. 467, 468 (1956). Interestingly, under Delaware law majority shareholders, defined as those owning at least $50 \%$ of outstanding common shares, are considered controlling shareholders per se, whether or not they actually exercised control over their corporation at all. Lewis, 699 F.2d at 235. 
decisionmaking in this area and the ability of creditors to police themselves are enhanced.

This Comment argues that a creditor, especially a financial institution, may closely resemble a controlling shareholder at a certain point in its relationship with its debtor. This resemblance usually occurs when the creditor continues to finance the debtor corporation, despite clear signals that the debtor's operations may be financially unstable, to such a degree that the financial institution, not the holders of the corporation's equity, have financed the major portion of the debtor's assets. This fact, coupled with the creditor's ability to manipulate the debtor via provisions in the loan agreement or through a collateral pledge of the debtor's stock, transforms such a creditor into a quasi-controlling stockholder. Since a controlling shareholder has clearly defined fiduciary duties to its corporation, minority shareholders, and outside creditors, a financial institution finding itself in this predicament should also be imbued with these duties.

Imposing these duties on controlling creditors helps prevent them from advancing their interests at a time when neither the debtor's shareholders nor the competing creditors can protect themselves adequately. This Comment, however, does not advocate imposing these duties lightly. As will be explored in greater detail below, controlling creditors should only be required to act in a fiduciary capacity after two events occur. First, the creditors must have failed to heed the signals that the debtor was experiencing serious difficulties and to have taken the appropriate action to protect their investment to the furthest extent legally possible. Second, the creditors must have taken on the dual indicia of control set out below.

\section{A. The Similarities Between Controlling Creditors, Ordinary Shareholders, and Controlling Shareholders}

Lenders always have at least one thing in common with ordinary shareholders and controlling shareholders: they have contributed financial resources to the debtor's enterprise so that the debtor may purchase assets or pay down liabilities. ${ }^{102}$ The debt-equity ratio typically is used to analyze the proportion of leverage in a debtor's business. ${ }^{103}$ This

102 This proposition, of course, is based on the assumption that the ordinary and controlling shareholders were the primary, not secondary, purchasers of stock in the debtor corporation.

103 The debt-equity ratio is calculated as follows:

Debt-equity ratio $=\frac{\text { Long-term debt }+ \text { Value of Leases } \times 100}{\text { Equity }}=\%$ Since long-term lease agreements also commit the debtor to a series of fixed payments, 
ratio highlights the particular percenitage of the debtor's assets that "belong" to the debtor's creditors. As the financial contribution to the debtor by a creditor or group of creditors grows, ceteris paribus, this ratio increases. Such an increase, in turn, may lead to a very curious, but undeniable, result:

When this percentage is over 100 percent, then creditors' equity exceeds that of the [shareholders]. As the percentage grows, creditors have less and less protection in the event of liquidation. Debt can grow to the point where it is the creditors who actually own the business and have a greater stake in the outcome of business decisions than the owners. ${ }^{104}$

Common sense would dictate that at a ratio of $100 \%$ and beyond, the actions taken by a major lender toward its debtor will resemble those normally exhibited by shareholders, and not those of typical creditors. Indeed, Oliver Williamson suggests that "[a]s the exposure to risk increases, . . . debt holders become more concerned with the details of the firm's operating decisions and strategic plans: With high debt-equity ratios the creditors become more like shareholders and greater consultation between the management and its major creditors results."105 This inference that creditors could be classified as quasi-shareholders in certain circumstances is further bolstered through a comparison of the specific powers of a shareholder with those of a lender. This is especially true when the particular lender is one whose loans represent a substantial part of the liabilities on the debtor's balance sheet.

Generally, shareholders have the ability to exercise both intra- and extracorporate powers on account of their equity positions. Two significant intracorporate powers are meaningful in the control context. ${ }^{108}$

commentators advise including the value of lease obligations with the debtor's long-term debt when calculating the ratio. See R. BREALEY \& S. MYERS, supra note 7, at 57071.

104 Bryan, Financial Analysis and the Key Business Ratios, in BaNk CREDIT 27, 35 (H. Prochnow ed. 1981) (emphasis added); see also J. Weston \& E. Brigham, supra note 28, at 29-30, 663-93 (discussing the concept of leverage in general).

105 Williamson, supra note 5, at 1212 (citing M. KIng, PUblic Policy AND THE Corporation 156 (1966)) (emphasis added). It should be noted that Williamson makes this statement with regard to corporations existing in countries where the stock market is poorly-developed and thus are required to rely more extensively on debt. However, the same result occurs in countries with highly-developed capital markets when corporations, either by choice or necessity, find themselves relying on large amounts of debt to finance their operations.

${ }^{108}$ Weston and Brigham classify the general rights of holders of common stock into "collective" and "specific" rights. Collective rights include the power: (1) to amend the charter (with appropriate state approval); (2) to adopt and amend by-laws; (3) to elect the directors of the corporation; (4) to authorize the sale of fixed assets; (5) to enter into mergers; (6) to change the amount of authorized common stock; and (7) to 
The first is the power to elect or remove directors. This power is linked to the voting rights of the shares of stocks and can be increased via the acquisition of additional shares of such stock. The second power is the ability to ratify, veto, or modify proposed changes in the corporate form or direction. This power is also linked to the voting rights of the outstanding shares of stock. Shareholders, however, also have a substantial extracorporate power with which to influence the corporation. That power is the ability to sell their shares on the open market, which, in turn, may alert an efficient capital market as to the potential of that particular corporation to operate profitably. ${ }^{107}$ In fact, many commentators believe that shareholders' collective ability to affect the market price of the firm's stock through purchase or sale activities, not their voting powers, represents the shareholders' major influence over the corporation. ${ }^{108}$

Creditors also have power over their debtors. Part I of this Comment described various methods through which a creditor may gain and subsequently exercise control over its debtor. Through the use of covenants, both negative and positive, as well as through other means, a financial institution often wields powers similar or even superior to those mentioned above with regard to ordinary shareholders of a corporation.

For instance, a creditor may gain voting control of the debtor corporation and be in a position to force the debtor to accede to its demands. Voting control is acquired by a creditor mainly in one of three ways: (1) as a trustee of a voting trust; (2) as holder of an irrevocable proxy; or (3) as a pledgee of shares with power to vote a controlling block of the debtor's stock. ${ }^{109}$ With such control, a creditor is in a position to elect or remove directors. Voting control likewise provides a creditor with the capability to influence or even dictate the corporate direction. With regard to extracorporate powers, creditors possess the means to send signals to the market via their selective distribution of information about a particular debtor, such as when a third party requests details concerning a debtor's creditworthiness. ${ }^{110}$

issue preferred stock, debentures, bonds, and other securities. Specific rights of common stockholders, on the other hand, include the power: (1) to vote in the manner prescribed by the corporate charter; (2) to sell their stock to other persons; (3) to inspect the corporate books (a limited right); and (4) to share in the residual assets of the corporation on dissolution. See J. WeSTON \& E. BRIGHAM, supra note 28, at 483-84.

${ }_{107}$ See Clark, The Four Stages of Capitalism: Reflections on Investment Management Treatises, 94 HARV. L. REv. 561, 570 (1981) (arguing that corporate managers are strongly disciplined by effectively functioning capital markets).

108 See, e.g., G. Pinches, supra note 27, at 530.

${ }^{108}$ See Douglas-Hamilton, supra note 32, at 401.

${ }^{110}$ See Bank of New Richmond v. Production Credit Ass'n (In re Osborne) 342 
These signals take on added significance when viewed in light of creditors' informational superiority. ${ }^{111}$ Creditors frequently access intricate information about debtors' operations. This gives them an edge in utilizing their powers to enforce their rights. In sum, the powers described above coupled with informational access afford creditors the ability to control the debtor in a manner which promotes their best interests and not those of the corporation or weaker creditors.

Controlling creditors, of course, are not alone in holding significant power over the debtor corporation. Two other parties have manipulative abilities. The first and most obvious party is the Government. The second and often overlooked party, however, is the controlling shareholder. Controlling shareholders have extensive powers and access to information equivalent to those of creditors in a position of dominance. Consequently, the courts, when faced with a challenge to a creditor's control, could very well gain insight into the control issue by analyzing the rights and obligations of a controlling shareholder vis-à-vis those of her corporation.

\section{B. The Extension of Controlling Shareholders' Fiduciary Responsibilities to Controlling Creditors}

It is important to recognize that it is not unlawful for creditors to act in their own self-interest in most instances. ${ }^{112}$ Indeed, the fact that certain creditors are able to wield powers normally associated with typical holders of stock should not be viewed negatively per se. After all, common stockholders normally are allowed to act in their self-interest $^{113}$ while only the board of directors must act in the best interests of the corporation. ${ }^{114}$ Therefore, the vast majority of creditors involved in lending relationships also should be allowed to act in their own self-

Bankr. 988 (Bankr. W.D. Wis. 1984) (claims may be subordinated if creditors misrepresent the debtor's prospects of repayment in such a way as to deliberately deceive other creditors to the advantage of the misrepresenting creditor); Bergquist v. First Nat'l Bank (In re American Lumber Co.), 5 Bankr. 470 (Bankr. D. Minn. 1980) (lender's claim equitably subordinated for several reasons, including falsely advising a credit association that debtor was not bankrupt).

${ }^{111}$ See supra notes 26-29 and accompanying text.

112 See e.g., Cosoff v. Rodman (In re W.T. Grant Co.), 699 F.2d 599, 610 (2d Cir.), cert. denied, 464 U.S. 822 (1983) ("TT]here is generally no objection to a creditor's using his bargaining position, including his ability to refuse to make further loans needed by the debtor, to improve the status of his existing claims.").

${ }^{113}$ H. HENN \& J. AlEXANDER, supra note 50, at 653 ("Shares are the private property of the shareholders who traditionally are allowed to vote the shares as they desire.").

${ }_{114}$ See In re Reading Co., 711 F.2d 509, 517 (3d Cir. 1983); Unocal Corp. v. Mesa Petroleum Co., 493 A.2d 946, 955 (Del. 1985). 
interests, so long as no fraud or other vice is committed in so doing. ${ }^{115}$

But situations do arise when even a shareholder is saddled with the responsibility of exercising her powers for the good of the corporation. ${ }^{116}$ One instance is when a shareholder dominates her corporation. A controlling shareholder has the ability to use her power to the detriment of the corporation in general and at the expense of the minority shareholders in particular. ${ }^{117}$ As Victor Brudney explains:

Controlling stockholders, like managers, presumably act like economic agents seeking to maximize the return to themselves-even at the expense of other stockholders. Controlling stockholders may be management or they may simply install a management which does their bidding or what it believes to be appropriate to serve the controllers' special interests. In either case, the temptation to divert common assets to the controllers at the expense of the other stockholders is the inevitable concomitant of "control.". . .

It is to be noted, however, that management and directors in authorizing use of corporate assets or directing corporate transactions are said to owe their obligations to the corporation, and not, at least at the expense of the corporation, to particular stockholders, or to one group of stockholders rather than another. As a consequence, in litigation challenging particular transactions as favoring controlling stockholders, the legal questions are generally addressed to whether the asserted managerial behavior improperly diminishes, or fails to enhance, corporate wealth while conferring a collateral or added benefit on controlling stockholders. ${ }^{118}$

118 See W.T. Grant, 699 F.2d at 610; Note, Corporations-Voting by Shareholders-Duty of Creditor Holding Voting Control, 14 U. CHI. L. REv. 92, 95 (1946) (arguing that a creditor in control should be afforded a wide latitude of permissible conduct, except when it is guilty of misfeasance and nonfeasance); supra note 65 and accompanying text.

${ }_{118}$ See Frankel, Fiduciary Law, 71 Calif. L. Rev. 795, 795-96 (1983) (stating that a controlling shareholder's fiduciary duties are a product of legal developments occurring in this century).

${ }^{117}$ See generally Sneed, Stockholder Votes Motivated by Adverse Interest: The Attack and the Defense, $58 \mathrm{MrcH}$. L. REv. 961, 997-98 (1960) (explaining the ways in which majority stockholders may vote to achieve personal and pecuniary gain at the expense of other stockholders).

118 Brudney, Equal Treatment of Shareholders in Corporate Distributions and Reorganizations, 71 GaLIF. L. REv. 1072, 1074 n.4 (1983) (footnotes omitted); see also H. HENN \& J. AleXANDER, supra note 50, at 654:

The fiduciary duties imposed on controlling shareholders with respect to corporate affairs have been predicated on two bases: (a) a direct approach, based on equitable principles that one who holds a position of 
In recognition of this fact, the Supreme Court ruled in 1939 that controlling shareholders must act as fiduciaries towards their corporations. In Pepper v. Litton, ${ }^{118}$ the Court stated:

Their dealings with the corporation are subjected to rigorous scrutiny and where any of their contracts or engagements with the corporation is challenged the burden is on the . . . stockholder not only to prove the good faith of the transaction but also to show its inherent fairness from the viewpoint of the corporation and those interested therein. ${ }^{120}$

This Comment argues, consequently, that when a creditor resembles a controlling shareholder, it too should be imbued with corresponding fiduciary obligations.

This resemblance occurs when the creditor has taken on dual indicia of control over its debtor. First, the creditor must have significantly funded a debtor's operations to the extent that, if the total credit injection originally had been one of equity, the creditor, if viewed as a shareholder, would have been required to act as a fiduciary towards the corporation. Second, the creditor must have obtained powers over the debtor either through a pledge of voting stock taken as collateral or through the use of restrictions contained in the loan agreement, or both. ${ }^{121}$ Consequently, when a creditor fails to heed the signals that the

superiority and influence over the interests of others is a fiduciary, concluding that the relationship of controlling shareholders to minority shareholders is a fiduciary relationship, or (b) an indirect approach to the effect that if the officers and directors owe fiduciary duties, the controlling shareholders who dominate the corporation through their influence over the directors and officers are subject to analogous duties.

Id. (footnotes omitted); Comment, The Fiduciary Relation of the Dominant Shareholder to the Minority Shareholders, 9 HAstings L.J. 306, 307-310 (1958) (describing the ability of dominating shareholders to directly or indirectly influence the corporation to the detriment of minority shareholders).

118308 U.S. 295, 306 (1939); see also Davis, Judicial Review of Fiduciary Decisionmaking-Some Theoretical Perspectives, 80 Nw. U.L. Rev. 1 (1985). Davis remarks:

Necessarily, the personal interests of the controlling party, the fiduciary, and the person whose affairs and assets are subject to control, the principal, will from time to time diverge. Through the fiduciary device, the law seeks to create a system of compensation and deterrence to protect the principal's interests against exploitation which results from that divergence.

Id. at 1 .

120 Pepper, 308 U.S. at 306.

${ }^{121} \mathrm{Cf}$. Kaplan, Fiduciary Responsibility in the Management of the Corporation, 31 Bus. Law. 883 (1976). He states, "In discussing the ambit of fiduciary responsibility ... we are speaking about the obligations of directors . . . and controlling shareholders (with whom shall be included parent corporations, majority shareholders and 
debtor is experiencing financial difficulty and later comes to evidence these two indicators of control, then that creditor should be treated as a quasi-controlling shareholder. ${ }^{\mathbf{2 2}}$

Courts' treatment of shareholder loans to undercapitalized corporations support this argument. Stockholder loans to corporations with insignificant equity cushions may be treated as capital injections, not debt financing, regardless of whether or not they are secured. ${ }^{123}$ The district court in In re Fett Roofing and Sheet Metal Co., Inc. ${ }^{124}$ did just that. The corporation's inception had been accompanied with minimal capitalization, and, consequently, substantial advances from the sole shareholder were vital to the continuation of the business. Still, the corporation experienced economic difficulties. Eventually an involuntary petition for bankruptcy was filed by outside creditors. At the time of the petition the court determined that the corporation's debt-equity ratio was over 80 to $1 .{ }^{125}$ The court, however, argued "[w]hile this fact by itself will not serve to convert what is otherwise a bona fide loan into a contribution of capital, it does cast serious doubt on the advances . . . being considered debt rather than equity. ${ }^{2128}$ The court went on to point to other factors, including "the undisputed day-in-and-day-out

members of control groups)." Id. at 887 (emphasis added). Later, Kaplan adds, "[c]ontrol of a corporate enterprise has inherent within it many possibilities of the application of the fiduciary doctrine." Id. at 907.

Koch, when addressing the "control" issue with regard to insider status under the Bankruptcy Code, states that caselaw suggests "that the mere taking of a stock pledge to secure repayment of a loan, by itself, does not create a control relationship." Koch, supra note 5, at 803 (emphasis added). Consequently, this Comment ties together the extension of a significant amount of financing with other means of control, such as voting rights gained through a pledge agreement, to provide the requisite control needed to impose fiduciary duties. See also infra notes 123-28 and accompanying text (discussing the ability of courts to declare a shareholder's loans to her corporation to be equity injections when the corporation is undercapitalized and the shareholder in question controls the corporation).

${ }_{122}$ The timing of the financing-ratio test would be based on the debtor's current financial condition; thus, courts should measure the extent to which the current value of the creditor's layer of financing exceeds the value attributable to the equity layer. Exactly what the original funding agreement entailed is largely irrelevant because the focus is on the additional funding given to a debtor after its creditor has become cognizant of the debtor's financial instability. But see infra note 150.

${ }^{123}$ See Pepper, 308 U.S. at 309-10 ("[S]o-called loans or advances by the dominant or controlling stockholder will be subordinated . . . and thus treated in effect as capital contributions by the stockholder . . . where the paid-in capital is purely nominal . . . ."); Benjamin v. Diamond (In re Mobile Steel Co.), 563 F.2d 692, 702-03 (5th Cir. 1977); Kagen v. Martin (In re Tufts Electronics, Inc.), 34 Bankr. 455, 459 (Bankr. D. Mass. 1983) (requiring that loans by stockholders be examined as likely contributions to capital where corporation is undercapitalized).

${ }^{124}$ Fett v. Moore (In re Fett Roofing \& Sheet Metal Co.), 438 F. Supp. 726

(E.D. Va. 1977).

${ }_{125}$ Id. at 730 .

${ }^{126} I d$. (emphasis added). 
control over corporate affairs wielded by [the stockholder],"127 which mandated that the debt be treated as equity. ${ }^{128}$

This Comment makes a similar argument: a court should consider both the extent to which a creditor has financed its debtor and the ability of that creditor to control the debtor. If a creditor maintains these two indicators of control to the extent established in this Comment, then that creditor should have to satisfy the fiduciary responsibilities of a controlling shareholder. Even when a particular creditor is deemed a controlling creditor as defined in this Comment, that creditor may still retain many of the characteristics of an ordinary creditor. The most important of these characteristics, besides the fact that it normally cannot participate in the distribution of the corporation's profits, is the creditor's priority right to proceeds stemming from a corporate liquidation. ${ }^{129}$ Self-serving conduct by a controlling creditor, however, may result in a lowering of the shareholders' future dividend stream or, in the event of liquidation, in a reduction in the residual value of the corporation to which the shareholders are entitled. ${ }^{130}$

Self-serving conduct by a controlling creditor similarly may endanger the rights of competing creditors, preventing them from reaping the fruits of their investments in the debtor. Therefore, the extension of fiduciary duties to include a controlling creditor's actions affecting competing creditors is warranted. ${ }^{131}$ This extension, moreover, is consistent with court decisions holding that controlling shareholders owe fiduciary obligations "designed for the protection of the entire community of interests in the corporation-creditors as well as stockholders."132 This is

127 Id.

128 Id. at 731.

128 See 11 U.S.C. $§ 726$ (1982) (entitled "Distribution of property of the estate"-establishing a priority schedule for distribution of the bankrupt's estate among various creditor claimants in a chapter 7 proceeding).

${ }^{130}$ See 11 U.S.C. $\$ 726(a)(6)(1982)$.

131 One could argue that since the controlling shareholder as defined in this Comment really has the "equity" in the debtor, it should be protected by the limited liability rule of corporate shareholders. "Mere control" is usually not enough to pierce the veil. But the issue here is not whether the controlling creditor has control per se; rather, it is on how it uses that control once obtained. Controlling shareholders, moreover, have duties that extend beyond those of a typical shareholder. These duties include ensuring that they act to protect all involved with the debtor corporation. See infra notes 132-33 and accompanying text. Consequently, the controlling creditor who has acted to the detriment of competing creditors, like its shareholder counterpart, has transcended the limited liability rule and must confront the consequences of its actions.

192 Superintendent of Ins. v. Bankers Life \& Casualty Co., 404 U.S. 6, 12 (1971) (citation omitted); see Bailey v. Meister Brau, Inc., 535 F.2d 982, 993 (7th Cir. 1976) (stating that a controlling stockholder's fiduciary obligations to the entire community of interests in the corporation require disclosure reflecting on fairness of transactions that affect the corporation). 
particularly true when controlling shareholders seek to interpose claims against the corporation to the detriment of other creditors. ${ }^{133}$

\section{Elements of a Controlling Creditor's Fiduciary Duty to the Corporation, Minority Shareholders, and Competing Creditors}

If one accepts the argument for treating certain creditors like controlling shareholders with accompanying fiduciary duties, then the problem arises as to which standard or standards should be utilized to assess whether a controlling creditor has breached these duties. This problem is particularly acute, since fiduciary standards in general are evasive:

The very definition of a fiduciary is nebulous and uncertain; the meaning of the concept of fiduciary responsibility is likewise imprecise and unsure. Although there are many judicial opinions holding that specific conduct is or is not required of a particular defendant, who is alleged to be a fiduciary, and although there are many individual decisions concerning whether a specific course of conduct was within or without the realm of fiduciary responsibility, there has been little or no effort to define fiduciary or to describe what a fiduciary is. ${ }^{134}$

Still, since this Comment focuses upon the controlling shareholder, determining her duties to the corporation and then applying them to the controlling creditor by analogy would prove beneficial. Therefore, a discussion of these duties in light of both current case law and proposed standards recommended by the American Law Institute follows.

Case law establishes that a controlling shareholder will fulfill her fiduciary duties if her interactions with the corporation meet the standards of good faith and fair dealing. ${ }^{135}$ Above all else, this translates

133 See First Nat'l Bank v. Overmyer (In re Overmyer), 53 Bankr. 952, 957 (Bankr. S.D.N.Y. 1985) (noting that the fiduciary relationship of a majority shareholder to her corporation may be extended to creditors of the corporation when the shareholder seeks to interpose claims against the corporation that injure creditors).

134 Kaplan, supra note 121, at 886. Kaplan further argues, "the designation of someone as a fiduciary merely initiates our inquiry into the precise nature of that particular person's obligations." Id. (footnote omitted); see also Davis, supra note 119, at 23 ("What we see as we survey the landscape of fiduciary law is a diverse and often inconsistent variety of legal rules.").

${ }_{18 s}$ See Concrete Ready-Mix v. Country Green Ltd. Partnership (In re County Green Ltd. Partnership), 438 F. Supp. 701, 707 (W.D. Va. 1977), rev'd, 604 F.2d 289 (1979) (controlling shareholder breached fiduciary duty to corporation and its creditors by using corporate entity as a "mere tool of expediency" to carry out personal business and, thus, did not meet standard of good faith and fair dealing). 
into a prohibition on self-dealing transactions. ${ }^{136}$ Self-dealing encompasses activities that cause the dominated corporation to act in such a way that the controlling stockholder receives something from the corporation to the exclusion and/or detriment of minority shareholders. ${ }^{137}$ Consequently, the controlling stockholder neither can deny the minority shareholders a meaningful role in the governance of the corporation ${ }^{138}$ nor injure the minority through its own mismanagement. ${ }^{139}$ In addition, she can neither convert corporate assets to her individual pursuits ${ }^{\mathbf{1 4 0}}$ nor utilize her power to effectuate transactions intended solely to maintain or increase her power. ${ }^{141}$

When these duties are imposed on creditors in those situations in which such duties are warranted, the implications are clear. Controlling creditors cannot manipulate the debtor's board of directors with impunity. Such conduct is a breach of their fiduciary responsibilities if

${ }^{136}$ See Orchard v. Covelli, 590 F. Supp. 1548, 1560 (W.D. Pa. 1984) (systematic effort by majority shareholder of corporation to exclude minority shareholder from any meaningful role in the corporation, as well as an effort to deny her the benefits therefrom, constitutes self-dealing by majority shareholder and entitles minority shareholder to fair value of her interest in the corporation).

${ }_{137}$ See In re Reading Co., 711 F.2d 509, 518 (3rd Cir. 1983). "[S]elf-dealing occurs when the majority shareholders cause the dominated corporation to act in such a way that the majority shareholders receive something from the corporation to the exclusion and detriment of minority shareholders." The court iterated this definition in the course of holding that complainant Reading had not been denied rightful access to corporate assets. See also Eagle v. AT\&T, 769 F.2d 541, 545 (9th Cir. 1985) (inferring that a controlling shareholder breaches fiduciary duty when controlling position is used to elect directors who then implement controlling shareholder's self-serving policies to the detriment of minority shareholders).

${ }_{188}$ See Covelli, 590 F. Supp. at 1558 (excluding a minority shareholder from a meaningful role in the corporate decisionmaking process constitutes breach of majority shareholder's fiduciary duties).

${ }_{139}$ See Crocker v. McMullan, 623 F. Supp. 963, 968 (S.D. Miss. 1985) (stating that minority shareholder may sue directors and officers who were also controlling shareholders where mismanagement allegedly rendered plaintiff's stock worthless); see also KDT Indus. v. Home Ins. Co., 603 F. Supp. 861, 868 (D. Mass. 1985) (stating that a controlling shareholder cannot transfer her control to a third party when it is reasonably likely that the buyer thereafter will harm the interests of the minority shareholders).

${ }_{140}$ See Silverman \& Sons Realty Trust v. Commissioner, 620 F.2d 314, 318 (1st Cir. 1980) (holding that majority shareholders have no legal entitlement to use corporate property in their individual capacities, but rather owe to each other and to minority shareholders certain fiduciary duties which limit their capacity to convert corporate property to their own individual purposes); see also 1 FLETCHER's Cyclopedia of CoRporations \& 31, at 345 (1983) ("The property of the corporation is its property, and not that of the stockholders' as owners, but they have equities in it . . ." (footnote omitted)).

${ }_{141}$ See Wright v. Heizer Corp., 560 F.2d 236, 251 (7th Cir. 1977) (failure of majority shareholder to disclose to other shareholders all the facts surrounding a proposed increase in the number of authorized shares of common stock constitutes breach of fiduciary duty by using corporate machinery to effect a transaction intended solely to maintain majority shareholder's control over the corporation). 
the manipulation results in an impairment of shareholders' or competing creditors' interests. Any control exerted over the board must work for the corporation's best interests and not solely for those of the controlling creditor. Indeed, the controlling creditor must yield to the shareholders' legitimate right to govern the corporation.

The controlling creditor also cannot force transactions through the corporation that increase its security at the expense of competing creditors. Moreover, this prohibition would be in effect even if the bankruptcy preference window had not opened. ${ }^{\mathbf{1 4 2}}$ Nor can the controlling creditor pressure the debtor to take actions to pay back its obligations in a manner detrimental to the rights of interested parties. This means that the creditor cannot compel the debtor to raise additional capital for the sole purpose of paying amounts owed to the creditor. This could dilute the shareholders' interests against their will. Similarly, the creditor cannot direct the debtor to sell off capital assets and transfer the proceeds to the creditor to satisfy its debt. This could adversely affect the going-concern potential of the debtor, or, in the event of bankruptcy, decrease the debtor's residual value.

An analysis of the American Law Institute's Principles of Corporate Governance ${ }^{\mathbf{1 4 3}}$ offers results similar to those above. Two sections of the ALI are pertinent to this discussion. ${ }^{\mathbf{1 4 4}}$ The first, section 5.10,

14211 U.S.C. $\S 547$ (b) (1982 \& Supp. III 1985). This provision states:

(b) Except as provided in subsection (c) of this section, the trustee may avoid any transfer of an interest of the debtor in property-

(1) to or for the benefit of a creditor;

(2) for or on account of an antecedent debt owed by the debtor before such transfer was made;

(3) made while the debtor was insolvent;

(4) made-

(A) on or within 90 days before the date of the filing of the petition; or

(B) between ninety days and one year before the date of the filing of

the petition, if such creditor at the time of such transfer was an insider;

(5) that enables such creditor to receive more than such creditor would receive if-

(A) the case were a case under chapter 7 of this title;

(B) the transfer had not been made; and

(C) such creditor received payment of such debt to the extent pro-

vided by the provisions of this title.

Id. (emphasis added). A creditor whose investment constituted a substantial portion of the right side of the debtor's balance sheet and who also maintained the indicia of a shareholder would most likely be classified as an "insider" under $\S 101(25)(B)(i i i)$ of the Bankruptcy Code. 11 U.S.C. $§ 101$ (25)(B)(iii) (1982) (defining insiders as persons in control of the debtor, if the debtor is a corporation).

143 Principles of Corporate Governance: Analysis and RecommendaTions, Pt. V. (Tent. Draft No. 5, 1986). Chapter 3 sets out the duty of loyalty of dominating or controlling shareholders.

144 These sections are as follows: 


\section{involves a dominating shareholder's duty of loyalty when she engages in}

$\S 5.10$. Transactions with the Corporation

(a) General Rule. A dominating shareholder [\$ 1.12] who enters into a transaction with the corporation fulfills his duty of loyalty to the corporation concerning the transaction if:

(1) the transaction is fair to the corporation when entered into; or

(2) the transaction is authorized or ratified by disinterested shareholders [\$1.11], following disclosure concerning the conflict of interest $[\S 1.09(\mathrm{a})]$ and the transaction $[\S 1.09(\mathrm{~b})]$, and does not constitute a waste of corporate assets at the time of the shareholder action [ $\S 1.34$ ].

(b) Burden of Proof. A party who challenges a transaction between a dominating shareholder and the corporation has the burden of proof, except that if the transaction was not authorized or ratified by disinterested shareholders, following such disclosure, the dominating shareholder has the burden of proving that the transaction is fair to the corporation.

$\S$ 5.11. Use of Dominating Position, Non-public Information Concerning the Corporation, or Corporate Property

(a) General Rule. A dominating shareholder [§ 1.12] may not advance his pecuniary interest by using his dominating position, material non-public information concerning the corporation, or corporate property, in a manner that:

(1) causes reasonably foreseeable harm to the corporation or to its other shareholders in their capacity as shareholders; or

(2) allows him to secure a pecuniary benefit, including a pecuniary benefit received as a shareholder that is not made proportionately available to other shareholders similarly situated . . . , unless his conduct is authorized or ratified in accordance with the standards of $\S 5.10(a)(2)$ (transactions with the corporation), or, in case of use of corporate property or services, he gives fair value for any benefit received.

(b) Burden of Proof. A party who challenges the conduct of a dominating shareholder under the standards set forth in Subsection (a) has the burden of proof, except that the burden is on the dominating shareholder to prove that such conduct was fair to the corporation and its shareholders if he does not rely on an authorization or ratification by disinterested shareholders [ $\S 1.11$ ] that satisfies the standards of $\S 5.10(a)(2)$.

(c) Special Rules on Remedies

(1) Damages against a dominating shareholder for conduct that fails to meet the standard set forth in Subsection (a)(1) may be recovered only by a party (including the corporation) who is harmed by such conduct.

(2) In the event of a recovery by a shareholder based on a failure to meet the standards set forth in Subsections (a)(1) or (a)(2), the corporation is not entitled to recover for the same conduct based on a violation of Subsection (a)(2).

\section{Id. at $\S \S 5.10-.11$.}

The adoption of standards like the ones above has significant practical value. As Kaplan argues,

[The] clarity of description and precision in defining [fiduciary] duties might ... be better achieved through abandonment of so amorphous a term in favor of developing a more precise set of notions of duty and responsibility in connection with each of the separate capacities now lumped within the broad and nebulous term "fiduciary."

Kaplan, supra note 121, at 887 . But see Davis, supra note 119 , at 35 ("[T] instances of proper [fiduciary] decisionmaking typically are not so homogeneous that their essence may easily be captured through a single bright-line test."). 
various transactions with the corporation. ${ }^{145}$ When this occurs, the transactions either must be fair to the corporation or have been authorized or subsequently ratified by disinterested shareholders.

An abuse of this duty of loyalty in the controlling creditor context can be illustrated by the following example. ${ }^{146}$ Assume that the creditor, who was determined to be a "controlling creditor" as set out above, had been making substantial loans to the debtor corporation and indicated that it would consider making additional loans so long as the corporation assigned its past, present, and future receivables. If after receiving the assignment the creditor fails to make the loans, this type of bad faith would provide the basis for holding the controlling creditor liable for a breach of its fiduciary duties. Indeed, such behavior would neither be fair to the shareholders of the corporation nor to competing creditors, whether or not the corporation was facing bankruptcy.

The second duty of loyalty, section 5.11 , is a broad catch-all duty. It forbids the controlling shareholder to use her dominating position, material nonpublic information, or corporate property in certain ways. In particular, she cannot use them in a way that causes harm to the corporation or to its other shareholders, or that allows her to secure a monetary benefit disproportionate to those obtained by the other shareholders. ${ }^{147}$

When analyzing the last hypothetical in light of this section, a controlling creditor also would have violated this duty of loyalty. First, the receipt of additional collateral clearly advances the controlling cred-

145 See supra note 144 ( $\$ 5.10$ "Transactions with the Corporation").

${ }^{146}$ This hypothetical is given purely for illustrative purposes; consequently, the applicability of other laws to it, such as those governing fraudulent conveyances, is not discussed.

${ }^{147}$ See supra note 144 ( $\$ 5.11$ "Use of Dominating Position, Non-public Information Concerning the Corporation, or Corporate Property"). But see Kaplan, supra note 121 , at 888 ("The only . . . dut[y] which has surely been ascribed to the majority shareholder is the duty to be fair in dealings with the corporation . . .; in very few instances is an obligation to act primarily for the benefit of the corporation at the expense of the majority shareholder's own interests imposed.").

Still, the necessity of having the courts impose an obligation on a majority shareholder to act for the corporation's benefit, even if that shareholder's best interests are not promoted thereby, is clear, as Davis implies:

The ways in which the fiduciary may abuse [her control]. . . to further her own interests at the expense of the principal's are many and diverse. Most blatantly, the fiduciary may cheat the principal, either by appropriating his assets or by self-dealing on terms unfair to him.

... The fiduciary's capacity and incentive to engage in these various forms of conduct that provide value to herself at the expense of her principal is . . . "opportunism."

Davis, supra note 119 , at $4-5$. 
itor's pecuniary interest by further securing its position, yet hurts the corporation and the shareholders who only agreed to assign the additional collateral in exchange for the promise by the creditor that additional-funding would be forthcoming. Second, competing creditors also are injured by the assignment, because in the event of liquidation this assignment could work to undermine their chances of recouping their investments. Of course, if such a transaction took place within one year prior to the petition for bankruptcy, the bankruptcy trustee could overturn it via the preference provision of the Bankruptcy Code. ${ }^{148}$ However, if the transaction occurred before the one year preference window opened, the competing creditors could obtain no relief unless the controlling creditor had a fiduciary duty towards them.

\section{Recommendations to Creditors and Courts}

The best piece of advice for creditors concerned with lender liability is that prevention is the best cure. ${ }^{149}$ Creditors should ensure that they do not inadvertently assume the two indicators of control mentioned throughout Part III of this Comment. This means that lenders should avoid financing a corporation to a greater extent than the actual holders of equity. ${ }^{150}$ In addition, they should forego taking a pledge of the debtor's stock as collateral. After all, if the company proves financially unstable down the line, then this collateral will not afford a lender much security anyway. Moreover, if the pledge is accompanied by voting rights, then the creditor could open itself up to a charge that it manipulated the debtor to the other shareholders' and competing creditors' detriment.

Finally, the lender should not place a particular restriction in the loan agreement if it has no intention of enforcing it. Restrictions are most effective when enforced at the proper moment, e.g., when the debtor breaks a covenant. Of course, a good faith modification to a loan restriction after its violation is possible. ${ }^{151}$ But the creditor simply can-

148 See supra note 142.

149 See Douglas-Hamilton, supra note 32, at 399. See generally Chaitman, The Ten Commandments for Avoiding Lender Liability, THE SEcured LeNDER, Nov.Dec. 1986, at 10 (setting out a pragmatic approach to limit lender liability in light of current legal doctrine).

${ }_{100}$ The importance attached to the debtor's capital structure should be tempered in certain situations. For example, the extent of financing should not be viewed suspiciously when the borrower and the lender originally contracted that the lender would have more at stake in the borrower's business than the equity holders. This would be true when the lender finances a leveraged buy out of the borrower. Also, the extent of financing should not be a factor in a lender liability challenge if the borrower is a member of an industry that is characterized by its greater use of debt than equity.

${ }^{151}$ Another pitfall against which a lender should guard is that of establishing a 
not ignore that the covenant was broken and later, when it thinks it is getting in too deep, pull the seemingly forgotten covenant out of its bag of tricks to gain advantage.

If, however, the creditor finds that it has been dragged slowly into a situation where it has assumed the dual indicia of control, then it must proceed with caution. When attempting to recoup its investment, the creditor must only navigate the debtor corporation in such a way as to benefit the corporation first, and through this method, the shareholders and competing creditors, as well as itself. Significantly, since a majority stockholder has no duty to assist her ailing corporation financially and thereby shield it from financial collapse, ${ }^{162}$ no such duty should be imposed on the controlling creditor unless it has contractually obligated itself to do so. ${ }^{153}$

These fiduciary duties, while burdensome, make sense when viewed in light of the creditor's own actions taken prior to its having reached this plateau of control. The creditor, after all, was in a position to enforce the covenants within the loan agreement and, if necessary, to call the loan. ${ }^{\mathbf{1 5 4}}$ Normally, it is well informed about the financial condition of a debtor in which it has invested significant funds. ${ }^{\mathbf{1 5 5}}$ If it fails to enforce its contractual rights when the circumstances warrant such action, then it should be placed in the same boat as the debtor's shareholders and competing creditors to endure the storm together. ${ }^{156}$ Lund-

course of dealing that runs contrary to a loan provision. If this were to occur, the lender should attempt to amend the loan agreement accordingly, but only after reasonable notice is given to the debtor. See K.M.C. Co. v. Irving Trust Co., 757 F.2d 752, 759 (6th Cir. 1985) (lender's sudden refusal to grant advances to debtor up to debtor's line of credit limit broke established pattern of dealing and constituted breach of implied duties of good faith and fair dealing).

132 See Kelly v. Fahrney, 145 Ill. App. 80, 96 (1908), affd, 242 Ill. 240, 89 N.E. 984 (1909).

${ }_{153}$ Cf. Getty Oil Co. v. Skelly Oil Co., 267 A.2d 883, 888 (Del. Super. Ct. 1970). The court held that although the parent corporation owed a fiduciary duty to its subsidiary, this duty did not mandate self-sacrifice from the parent. The court based its argument on the fact that the parent corporation itself also has stockholders to which it owes fiduciary responsibilities. Similarly, a controlling creditor should not concede its interests to those of the debtor when such action could be classified as a "self-sacrifice," since it too has shareholders to which it owes fiduciary obligations.

${ }_{154}$ See supra note 18 (discussing common default provisions).

105 Indeed, the informational superiority that a controlling creditor has over ordinary shareholders and weaker creditors puts it in an unparalleled position to enforce its legal right to repayment. See supra notes 26-29 and accompanying text. In fact, James Cunningham argues that, if a lender has done its job by incorporating the proper covenants into the loan agreement, the lender will receive "an early warning of any material deterioration in the financial condition of the borrower." Cunningham, supra note 17 , at 244.

${ }_{108} \mathrm{H}$. Ronald Kibel, however, in his book about reviving financially troubled companies, implies that lenders refuse to do this:

The bankers want to get their loan repaid . . . . Rather than admit 
gren implies such a position:

A bright line for creditors might be this: If a creditor is at the point where it believes it is necessary to participate in most facets of [the debtor's] business affairs on a recurring basis and to direct such affairs to the exclusion of the debtor's officers or employees, the creditor should call the debt and begin proceedings to liquidate or sell the business. ${ }^{187}$

Further support for requiring controlling creditors to "weather the storm" is found by analyzing the effect given to a negative pledge clause $^{168}$ in a bond indenture when the debtor corporation is involved in a Chapter 11 reorganization. ${ }^{169}$ The conventional wisdom of lawyers, which falls in line with the rationale in Kelly v. Central Hanover

within their own organization that a mistake was made either in granting ... additional credit or in failing to stay on top of ... [the debtor's] operations, they find it easier to cast the blame on the "competence" and "credibility" of . . . [the debtor's] management. These are code words the bank may use to convince . . . [the debtor's top management] to be their "goat" and bow out.

H. KIBel, supra note 33, at 5; cf. Roe, Bankruptcy and Debt: A New Model for Corporate Reorganization, 83 Colum. L. Rev. 527 (1983). Roe describes creditors' conduct towards debtors in the reorganization context:

Creditors in general are not necessarily interested in maximizing the viability of the firm. Ordinarily, absent the desire for repeated dealings .... they want to obtain the greatest value as early as possible. They want to make the firm more viable only if viability enhances the chance or size of their repayment, or otherwise provides them with a greater net present value. . . Some creditors-those who would receive full value upon a slow liquidation [after reorganization] via [the issuance of new] debt [instruments]-have no interest in promoting firm viability.

Id. at 542-43. It seems plausible that this reorganization attitude of certain creditors would be very similar, if not the same, as that of creditors involved with extremely troubled debtors heading towards reorganization, since both of these groups of creditors face similar dilemmas.

${ }^{167}$ Lundgren, supra note 4, at 539 (emphasis added); see also Douglas-Hamilton, supra note 32 , at 398 . She offers this advice to lenders:

If you are a lender in control of a financially troubled debtor, you risk exposure to far greater losses than those you might suffer by not having your loan repaid in due course. You might prefer to stay out of trouble by returning to the "simple" relationship of creditor and debtor.

Id. (original emphasis omitted; remaining emphasis added).

158 "The typical negative pledge clause provides that a company and its subsidiaries may not mortgage described assets without equally and ratably securing the debentures. If a company issues bonds secured by a mortgage [in violation of the clause], the company must open up the mortgage and also secure the debentures, so that they share in the collateral equally (i.e., on a parity with the bonds) and ratably (i.e., on a proportionate basis)." McDaniel, supra note 20, at 867 (footnote omitted).

15811 U.S.C. $\$ \S 1101-1174$ (1982) (entitled "Chapter 11-Reorganization"). 
- Bank $\mathcal{F}^{2}$ Trust Co., ${ }^{100}$ is that debenture holders cannot enforce such a clause against the debtor and third party creditors during the reorganization. ${ }^{161}$ Consequently, the negative pledge clause is worthless to the debenture holders at that time. This clause, however, is meaningful if the debenture holders assert their rights under it at the time the violation occurs. ${ }^{162}$ In other words, the debenture holders are forced to live with their mistake if they forego asserting their rights upon discovery that the clause has been violated by the debtor and a competing creditor.

Creditors, therefore, who fail to protect themselves through the powers granted to them in the loan agreement, and who instead are slowly dragged into a situation similar to that of a controlling shareholder, should be treated similarly. This means that the controlling creditor should bear the business risk equally with all other participants by being held to the fiduciary standards of a controlling shareholder.

The courts, on the other hand, should look to see if a creditor has interacted with the debtor either as an actual creditor or as a quasicontrolling shareholder. If the two indicators of control are found, then the courts should recognize the lender for what it really is-a fiduciary of the debtor. The next step is to determine if the lender failed to perform as a fiduciary towards its debtor or competing creditors. Enforcing fiduciary duties when the creditor warrants them is crucial if the interests of the debtor, its shareholders, and competing creditors are to be protected.

\section{SUMMARY}

This Comment has argued that it is possible for a creditor, especially a financial institution, to closely resemble a controlling shareholder. This resemblance stems from the occurrence of two events. First, the creditor must have continued to finance the debtor corporation, despite clear signals that the debtor's operations increasingly were unstable, to the point that the financial institution, not the holders of the corporation's equity, has financed the major portion of the debtor's assets. Second, the creditor must maintain the ability to influence the

18011 F. Supp. 497 (S.D.N.Y. 1935), rev'd, 85 F.2d 61 (2d Cir. 1936).

${ }^{161}$ See id. at 511-12; D. Baird \& T. Jackson, Cases, Problems, and Materials on Security Interests in Personal Property 929-30 (1984); see also 2 G. Gilmore, Security Interests in Personal Property 1019 (1965) ("[W]hat the debenture cases really teach us is that it does no good to have all the law on your side if God is against you.").

${ }_{162}$ See Kelly, 11 F. Supp. at 510-11. 
debtor via covenants in the loan agreement or through a collateral pledge of the debtor's stock. When these two indicators of control are present, they transform the creditor into a quasi-controlling shareholder. Since controlling shareholders have clearly defined fiduciary responsibilities to the corporation and minority shareholders, a financial institution finding itself in this predicament should also assume these responsibilities. The imposition of these responsibilities serves to balance the power between a controlling creditor on one hand and the debtor and its entourage on the other. Consequently, the interests of the debtor, its shareholders, and competing creditors are all protected at a time when the debtor corporation is financially distressed. 
